\title{
Advances in cathode nanomaterials for lithium-ion batteries
}

\author{
C. M. Costa ${ }^{1}$, R. Gonçalves ${ }^{2}$, S. Lanceros-Méndez ${ }^{3, *}$ \\ ${ }^{1}$ Centro de Física, Universidade do Minho, 4710-057 Braga, Portugal \\ cmscosta@fisica.uminho.pt \\ ${ }^{2}$ Centro de Física, Universidade do Minho, 4710-057 Braga, Portugal \\ r.goncalves@fisica.uminho.pt \\ ${ }^{3}$ BCMaterials, Basque Center for Materials, Applications and Nanostructures, UPV/EHU Science \\ Park, 48940 Leioa, Spain \\ ${ }^{3}$ IKERBASQUE, Basque Foundation for Science, 48013, Bilbao, Spain \\ senentxu.lanceros@bcmaterials.net
}

\begin{abstract}
Energy resources, consumption, and management are among the most important issues of this century. Our dependence on fossil fuels should be changed by eco-friendlier renewable energies. Further, the generated electrical energy should be stored for improving mobile applications, being batteries the most used system for this purpose. Lithium-ion batteries are the most promising battery type and are composed of three main elements: cathode, anode and separator/electrolyte. The active material of the cathode is primarily responsible for the battery capacity, and for that reason, different cathode materials have been developed and explored for lithium-ion batteries. In the present work, the most relevant cathode materials are presented, their main properties and characteristics described and their advantage and disadvantage analyzed, allowing understand to which extend those material are suitable for specific applications in this field.
\end{abstract}

Keywords: Cathode, Active material, Lithium-ion batteries, Energy storage

\section{Introduction}

In order to reduce dependence on fossil fuels, eco-friendly renewable energies, such as wind, solar and biomass, must be increasingly used due to global warming caused by increasing energy use and population increase (Can Şener et al. 2018; and Mohtasham 2015).

The energy produced by these systems must be stored and batteries are the type of energy storage most used for different applications, such as, consumer electronics, medical applications, hybrid electric vehicles (HEVs) and pure electric vehicles 
(PEVs), among others, due to their high power and energy density (Diouf and Pode 2015; Goodenough and Park 2013; and Scrosati and Garche 2010). In particular, for HEVs and PEVs it is necessary to increase the energy density of batteries.

The main components of a lithium-ion battery are the two different current collectors, typically copper and aluminum, two electrodes (negative and positive) and the separator/electrolyte (Pistoia 2013).

The negative electrode, anode, should present a low potential in order to provide high cell voltage with the positive electrode, cathode, that is responsible for the cell capacity and cycle life (Inagaki et al. 2010; and Park et al. 2010).

Regardless of the type of electrode, they consist of an active material, a conductive material and a polymer binder at different ratios (Gören et al. 2015). These three components are typically mixed in a solvent where the polymer is dissolved, and the active material and the conductive additive are dispersed to obtain good dispersion without sedimentation.

Considering that the active material of the cathode is primarily responsible for the battery capacity, this chapter focuses on the recent advances in the active cathode materials most commonly used in lithium-ion batteries. Further, new opportunities in this field are discussed.

\subsection{Electrode main components}

Figure 1 shows a schematic representation of a battery and the main components of the electrodes. In the electrodes, each constituent has a specific function: the polymer binder has the role of binding the active material and conductive additive; the conductive additive increases the electrical conductivity of the electrode and, in the case of the active material for the cathode, lithium ions must enter and leave repeatedly, its structure containing a readily reducible/oxidable ion (Liu et al. 2016). In relation to the conductive additive, the most used materials are carbon black and acetylene black due to higher electrical conductivity and low cost (Fransson et al. 2001).

For the polymer binder, poly(vinylidene fluoride), PVDF, and poly(tetrafluoroethylene), PTFE, are the most used binders due to excellent mechanical strength, high chemical resistance and high melting temperature (Geaney \& O'Dwyer 2016; and Wang et al. 2017). 


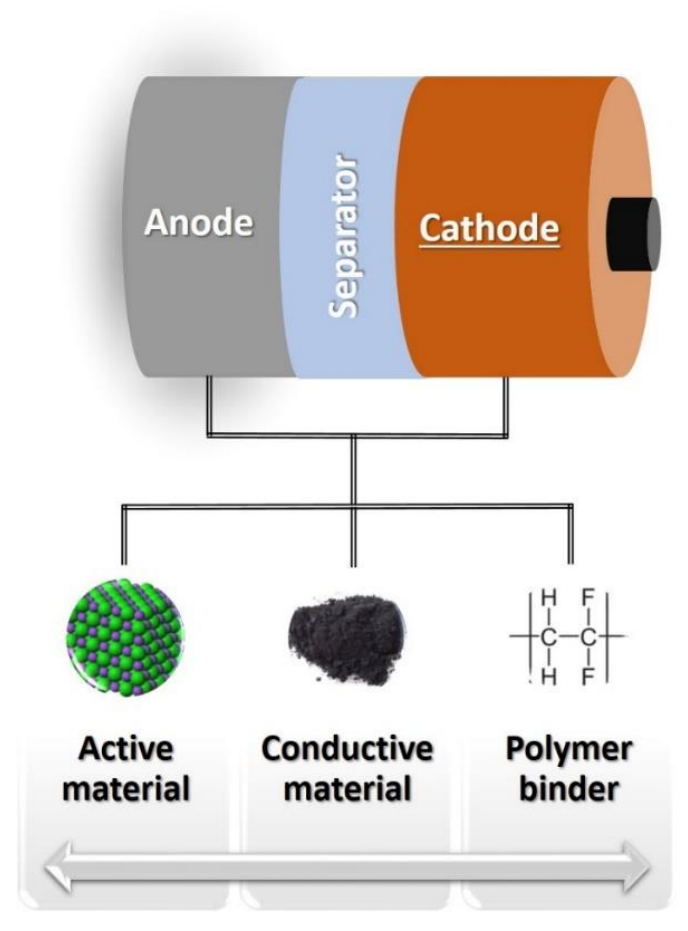

Fig. 1 Schematic representation of the battery and the main components of the electrodes.

The active materials used for cathode development must show high reactivity with lithium, incorporation of large amounts of lithium, reversibility in lithium incorporation with structural stability, high lithium diffusion, good electrical conductivity and insoluble in the electrolyte. The active materials most used in lithium-ion batteries are presented in Table 1 (Linden and Reddy 2002). Table 1 shows the crystal system, theoretical capacity, and typical potential for each active material.

Table 1. Most commonly active materials used for lithium-ion battery applications.

\begin{tabular}{ccccc}
\hline Active material & $\begin{array}{c}\text { Crystal system / } \\
\text { Space group } \\
\text { [Point Group] }\end{array}$ & $\begin{array}{c}\text { Specific } \\
\text { capacity/ } \\
\text { mAh.g }{ }^{-1}\end{array}$ & $\begin{array}{c}\text { Typical } \\
\text { voltage } \\
\text { range / V }\end{array}$ & Ref \\
\hline $\mathrm{LiCoO}_{2}$ & $\begin{array}{c}\text { Orthorhombic } / \\
\text { R3m }\left[\mathrm{C}_{3 \mathrm{v}}\right]\end{array}$ & 274 & $2.5-4.25$ & (Huang et al. 1998) \\
$\mathrm{LiFePO}_{4}$ & $\begin{array}{c}\text { Orthorhombic } / \\
\text { Pnma }\left[\mathrm{D}_{2 \mathrm{~h}}\right]\end{array}$ & 170 & $2.5-4.2$ & (Zhang 2011) \\
$\mathrm{LiCoPO}_{4}$ & $\begin{array}{c}\text { Orthorhombic } / \\
\text { Pnma }\left[\mathrm{D}_{2 \mathrm{~h}}\right]\end{array}$ & 167 & $3.0-5.1$ & (Gu et al. 2007) \\
$\mathrm{LiMnPO}_{4}$ & $\begin{array}{c}\text { Orthorhombic } / \\
\text { Pnma }\left[\mathrm{D}_{2 \mathrm{~h}}\right]\end{array}$ & 171 & $2.7-4.25$ & $\begin{array}{c}\text { (Martha } \text { et al. } \\
\text { 2009) }\end{array}$
\end{tabular}




\begin{tabular}{|c|c|c|c|c|}
\hline $\mathrm{LiMnO}_{2}$ & $\begin{array}{l}\text { Orthorhombic / } \\
\text { Pmmn }\left[\mathrm{D}_{2 \mathrm{~h}}\right]\end{array}$ & 285 & $1.0-4.6$ & (Jang et al. 1999) \\
\hline $\mathrm{LiMn}_{2} \mathrm{O}_{4}$ & Cubic / Fd $\overline{3} \mathrm{~m}\left[\mathrm{O}_{\mathrm{h}}\right]$ & 148 & $3.4-4.3$ & (Xia et al. 2012) \\
\hline $\mathrm{LiNiO}_{2}$ & $\begin{array}{c}\text { Trigonal / R3m } \\
{\left[\mathrm{C}_{3 \mathrm{~V}}\right]}\end{array}$ & 275 & $3.0-4.3$ & $\begin{array}{c}\text { (Yamada et al. } \\
\text { 1995) }\end{array}$ \\
\hline $\begin{array}{c}\mathrm{LiNi}_{1-\mathrm{x}} \mathrm{Co}_{\mathrm{x}} \mathrm{O}_{2} \\
(0.2 \leq \mathrm{x} \leq 0.5)\end{array}$ & $\begin{array}{l}\text { Rhombohedral / } \\
\text { R3m [C } 3 \text { } 3 \mathrm{v}]\end{array}$ & $\sim 275$ & $3.5-4.3$ & $\begin{array}{c}\text { (Adipranoto et al. } \\
\text { 2015) }\end{array}$ \\
\hline $\mathrm{LiNi}_{1 / 3} \mathrm{Mn}_{1 / 3} \mathrm{Co}_{1 / 3} \mathrm{O}_{2}$ & $\begin{array}{c}\text { Rhombohedral/ } \\
\left.\text { R3m [C } 3 \mathrm{C}_{3 \mathrm{v}}\right]\end{array}$ & 278 & $2.3-4.5$ & $\begin{array}{l}\text { (Julien et al. } \\
\text { 2016) }\end{array}$ \\
\hline $\mathrm{LiNi}_{0.5} \mathrm{Mn}_{0.5} \mathrm{O}_{2}$ & $\begin{array}{c}\text { Trigonal / R3m } \\
{\left[\mathrm{C}_{3 \mathrm{~V}}\right]}\end{array}$ & 280 & $2.5-4.9$ & $\begin{array}{l}\text { (Meng et al. } \\
\text { 2004) }\end{array}$ \\
\hline $\mathrm{LiV}_{2} \mathrm{O}_{5}$ & $\begin{array}{l}\text { Orthorhombic / } \\
\text { Pnma }\left[\mathrm{D}_{2 \mathrm{~h}}\right]\end{array}$ & 142 & $\begin{array}{c}2.50- \\
3.60\end{array}$ & $\begin{array}{c}\text { (Cava et al. } \\
\text { 1986) }\end{array}$ \\
\hline $\mathrm{LiV}_{3} \mathrm{O}_{8}$ & $\begin{array}{l}\text { Monoclinic / } \\
\mathrm{P} 2_{1} / \mathrm{m}\left[\mathrm{C}_{2 \mathrm{~h}}\right]\end{array}$ & 280 & 2.8 & (Idris et al. 2011) \\
\hline
\end{tabular}

These active materials are synthesized by different methods including mechanochemical activation, carbothermal reduction, microwave heating, hydrothermal synthesis, sol-gel synthesis, spray pyrolysis and co-precipitation, among others, in which their morphology and size are controlled (Bao et al. 2015; Beninati et al. 2009; Guan et al. 2017; Liu et al. 2008; Long et al. 2017; Ozawa et al. 2007; and Xiao et al. 2011).

It is to notice that each synthesis method shows specific advantages and disadvantages. Thus, the hydrothermal method is very used due to its low energy costs, low cost (relatively cheap reagents), pollution free (closed system reaction), large dispersion (reaction time), low operating temperature (facilitates industrialization), high reaction rate (higher efficiency) and nucleation control (Shandilya et al. 2016).

The control of morphology and particle size is essential for obtaining cathode electrodes with high cycling performance, as particles of small size show shorter $\mathrm{Li}^{+}$ ion diffusion length, which can further improve Li-ion migration rate (Chen et al. 2014b).

Further, in order to reduce the capacity fade and improve the electronic and ionic conductivity of these active materials, those structures have been doped with metal, non-metal or rare earth elements, among others (Liu et al. 2006b; and Xu et al. 2016).

\subsection{Recent advances in the most commonly used active materials}

In this chapter, each one of the active cathode materials reported in Table 1 will be addressed. For each one, the main properties, synthesis methods, and electrochemical properties will be presented. Some of the active materials are illustrated in Fig. 2 by its specific capacity versus cell voltage $\left(\mathrm{Li}^{+} / \mathrm{Li}\right)$ in order to compare their characteristics. 


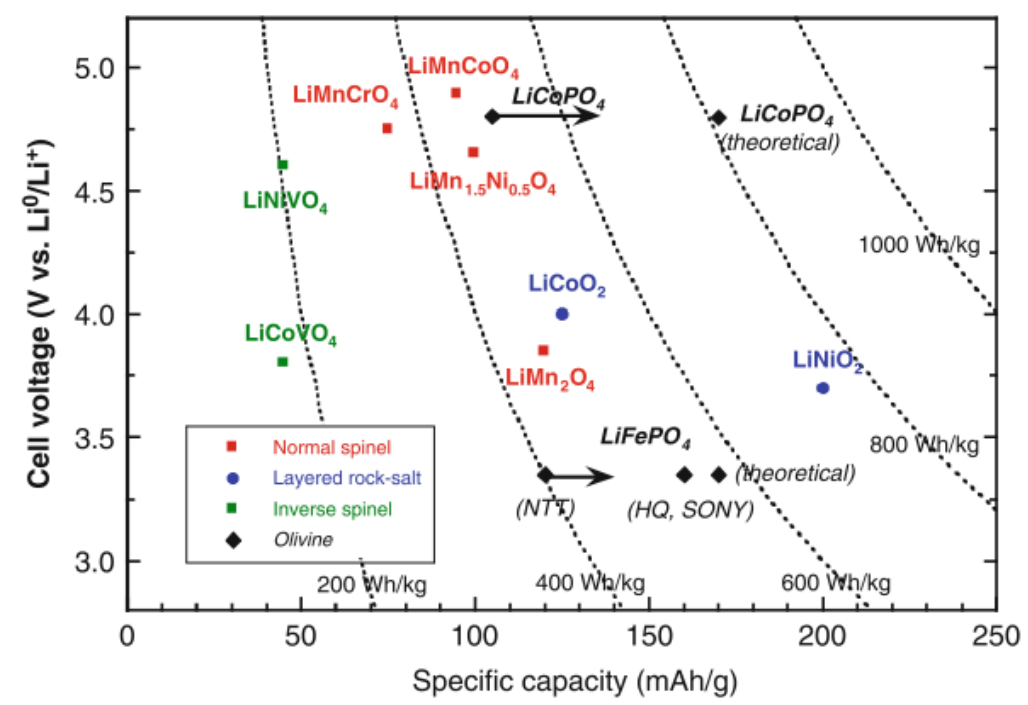

Fig. 2 Cell voltage versus capacity for different active materials (Julien et al. 2015).

\subsubsection{Lithium cobalt oxide $\left(\mathrm{LiCoO}_{2}\right)$}

Lithium cobalt oxide $\left(\mathrm{LiCoO}_{2}\right)$ has been one of the most widely used cathode materials in commercial Li-ion rechargeable batteries, due to its good capacity

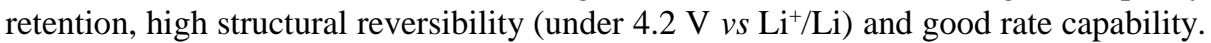
This active material was originally suggested by Goodenough et al. in 1976 and in the early 1990s Sony Corporation commercialized it (Daniel et al. 2014; and Mizuno et al. 2014). The undoped $\mathrm{LiCoO}_{2}$ cathode material shows a structure along the c-axis with $\mathrm{CoO}_{6}$ octahedra separated by $\mathrm{Li}^{+}$layers, where the $\mathrm{LiO}_{6}$ octahedra are elongated. The $\mathrm{LiCoO}_{2}$ unit cell in the hexagonal setting is composed of three layers in rhombohedral symmetry (Cherkouk and Nestler 2014). The layered $\mathrm{LiCoO}_{2}$ with the rhombohedral unit cell is characterized by a space group R3m with $a=2.8166 \AA$ and $c=14.045 \AA$ (Shao-Horn et al. 1999). The layered crystal structure of $\mathrm{LiCoO}_{2}$ with a density of 5.1 $\mathrm{g} \mathrm{cm}^{-3}$ is ideal to accommodate lithium ions. The active material also presents magnetic properties (Moradabadi and Kaghazchi 2015). This property led to different applications being its use in cathode material in lithium batteries one of the most promising due to the deintercalation of lithium $\mathrm{Li}_{\mathrm{x}} \mathrm{CoO}_{2}(\mathrm{x}<1)$. The experimental band gap $\left(\mathrm{E}_{\mathrm{g}}\right)$ is about $1.7-2.7 \mathrm{eV}$ (Andriyevsky et al. 2014).

A large anisotropic volume change is verified when $\mathrm{LiCoO}_{2}$ convert to $\mathrm{Li}_{0.5} \mathrm{CoO}_{1.5}$ during the charging. This volume change of the host lattice is about $7 \%$ and occurs in the c-axis direction. Consequently, it is verified a peeling between the conducting material and the active material particles that results in problems in capacity fade and poor rate capability of the cathode. The main reason for this fact is due to the material dispersion into the electrolyte (Mizuno et al. 2014). During the charge, the migration 
of $\mathrm{Li}^{+}$ions from the layered crystal lattice causes a nonstoichiometric $\mathrm{Li}_{1-\mathrm{x}} \mathrm{CoO}_{2}$ formation and the oxidation of $\mathrm{Co}^{3+}$ changes for charge compensation (Daniel et al. 2014).

The theoretical electrochemical capacity of $\mathrm{LiCoO}_{2}$ is around $274 \mathrm{mAh} \cdot \mathrm{g}^{-1}$, but due to the instability of the structure and the limitation of $\mathrm{Li}^{+}$removal from the hexagonal lattice (0.5), this capacity is reduced to around $140 \mathrm{mAh} \cdot \mathrm{g}^{-1}$ (Daniel et al. 2014).

Some efforts have been made in order to recycle the active material (Nie et al. 2015; Zhang et al. 2014). Zhang group used ultrasound radiation on $\mathrm{LiCoO}_{2}$ previous calcinated at $500{ }^{\circ} \mathrm{C}$ in order to remove all the carbon and binder of the cathode. The treatment consists of the application of hydrothermal ultrasound radiation during $6 \mathrm{~h}$ $(600 \mathrm{~W})$ at $80{ }^{\circ} \mathrm{C}$ in a concentrated solution of lithium hydroxide $(\mathrm{LiOH})$. The renovated active material shows a discharge capacity retention of 99.5 and a first discharge capacity of $133.5 \mathrm{mAh} . \mathrm{g}^{-1}$. It is shown that after 40 cycles the electrochemical properties of commercial batteries was achieved (Zhang et al. 2014).

Different methods and synthesis routes such as sol-gel (Balakrishnan et al. 2018; and Gao et al. 2015), flux-coating (Mizuno et al. 2014), one-step electrochemicalhydrothermal (Azib et al. 2015), combustion (Rodrigues et al. 2001), microwave (Hu et al. 2004), hydrothermal (Burukhin et al. 2002), thermal decomposition (Mizuno et al. 2012) and auto flame (Singh et al. 2018), were used to produce the $\mathrm{LiCoO}_{2}$.

In Azib's approach (Azib et al. 2015), thin films of $\mathrm{LiCoO}_{2}$ were synthesized via electrochemical-hydrothermal route using ethanol and water blends as a solvent. The influence of parameters such as ethanol-water ratio, pressure, temperature, current density and reaction time were evaluated on the $\mathrm{R} 3 \mathrm{~m}$ layered phase formation and in the electrochemical response of $\mathrm{Li}$ batteries. The results show that well-crystalized $\mathrm{LiCoO}_{2}$ with preferred orientation (101) without traces of spinel-like phase and cobalt oxide impurities were achieved and show a capacity of around $120 \mathrm{mAh} \cdot \mathrm{g}^{-1}$ (Azib et al. 2015).

In another study (Balakrishnan et al. 2018), thin films of $\mathrm{LiCoO}_{2}$ were prepared by spin coating deposition via a sol-gel process. The annealing temperature of $275{ }^{\circ} \mathrm{C}$ shows to be effective in the crystalline nature with a preferred orientation along the (003) plane of the rhombohedral structure. Above $416^{\circ} \mathrm{C}$, the material degrades. It was found that the conductivity of the samples decreases from $10^{-3}$ to $10^{-9} \Omega^{-1} \mathrm{~cm}^{-1}$ and that the band gap energy decreases from 2.51 to $3.4 \mathrm{eV}$ with annealing temperatures from 275 to $475{ }^{\circ} \mathrm{C}$, respectively.

Two kinds of crystallographic structures of the $\mathrm{LiCoO}_{2}$ can be achieved according to to the synthesis temperature. The cubic spinel structure is formed around $350{ }^{\circ} \mathrm{C}$ and around the $750{ }^{\circ} \mathrm{C}$, the layered trigonal (hexagonal) structure is formed. It is observed that the structure with the layered lattice shows a better electrochemical performance when compared with the structure with a cubic spinel lattice (Daniel et al. 2014).

Nanostructured approaches have been used in order to enable buffering of the stresses caused by the volume variation, improving the electrochemical performance and the structural durability through the increased surface area and decreasing the diffusion length of lithium ions in the extraction/insertion reaction. Higher capacities at high charge/discharge rates are achieved due to the shorter diffusion pathways for ionic transport and electronic conduction (Mizuno et al. 2014). 
Neutron scattering of a battery with $\mathrm{LiCoO}_{2}$ during the charge/discharge process shows no difference of the active material at $25{ }^{\circ} \mathrm{C}$ and $50{ }^{\circ} \mathrm{C}$ operation. In the same study, it was verified that the lattice parameter $\mathrm{c}$ of the rhombohedral structure and cell volume increases during the discharge process (more noticeable at $25^{\circ} \mathrm{C}$ ) (Cherkouk and Nestler 2014).

Different approaches to overcome the nanosized materials problems, such as particle aggregation that results in capacity fade due to low tap density and the not homogeneous distribution were evaluated. One of these methods was the grown of an additive-free nanosized-LiCoO 2 crystal layer directly on the current collector (Mizuno et al. 2014).

In order to improve the overcharge of the $\mathrm{LiCoO}_{2}$ (discharge energy of $96 \%$ ) a coating with $\mathrm{AlPO}_{4}$ was used and the over-insertion tolerance maintains to over $99 \%$ of the discharge energy after 10 cycles. Also, the $\mathrm{AlPO}_{4}$ coating prevents crystal structure changes and suppresses irreversible cation $\mathrm{Li}$ and $\mathrm{Co}$ exchange in the octahedral layers of the $\mathrm{LiCoO}_{2}$ during the over-insertion of $\mathrm{Li}^{+}$ions (Crompton et al. 2017).

\subsubsection{Lithium manganese oxide $\left(\mathrm{LiMnO}_{2}\right)$}

Lithium manganese oxide $\left(\mathrm{LiMnO}_{2}\right)$ layered structure is a very attractive material (compared to $\mathrm{LiCoO}_{2}$ ) from the environmental and economic perspective. This material shows two structures: orthorhombic with space group Pmmn and rhombohedral, being the orthorhombic structure thermodynamically stable. In order to obtain the layered material, the ion-exchange technique was used. Contrary, the rhombohedral structure is thermodynamically unstable due to the low spin of the $\mathrm{Mn}^{3+}(\mathrm{Wu} 2015$; and Zhang $\&$ Zhang 2015). Both of them involve distortion in the oxygen arrays from the ideal cubic close packing. The orthorhombic structure also shows the advantage of being easy to prepare and air stable, showing high capacity $\left(285 \mathrm{mAh} \cdot \mathrm{g}^{-1}\right)$ and high potential vs lithium. Other advantages are also observed once the reduction of manages oxide $\left(\mathrm{MnO}_{2}\right)$ does not release gases and $\mathrm{MnO}_{2}$ is a low-cost material (Shao-Horn et al. 1999). Lithium manganese oxide batteries were first used to power calculators, memory backups and watches. This material is the most common active material used in lithium batteries with $80 \%$ of the market share (Julien et al. 2015).

During the cycling process, it is observed poor electrochemical properties and a drop in the voltage profile, due to both orthorhombic and rhombohedral $\mathrm{LiMnO}_{2}$ transformation in a spinel structure, once this phase shows low crystallinity, Mn dissolution and large strain (Jahn-Teller activity) (Zhang and Zhang 2015). Jin group observed the transformation of orthorhombic lithium manages oxide $\left(\mathrm{LiMnO}_{2}\right)$ to spinel $\mathrm{LiMnO}_{2}$ phase during cyclic voltammetry (Fig. 3) (Jin et al. 2009; Radin et al. 2017). The main difficulty in obtaining layered $\mathrm{LiMnO}_{2}$ (compared with $\mathrm{LiCoO}_{2}$ and $\mathrm{LiNiO}_{2}$ ) is attributed to the fact the ion $\mathrm{Mn}^{3+}$ and $\mathrm{Li}^{+}$have the closer size (Radin et al. 2017). 
In order to stabilize the layered structure different approaches with cation doping with aluminum $(\mathrm{Al})$, cobalt $(\mathrm{Co})$, chromium $(\mathrm{Cr})$, titanium $(\mathrm{Ti})$, among others, were carried out (Ceder and Mishra 1999).

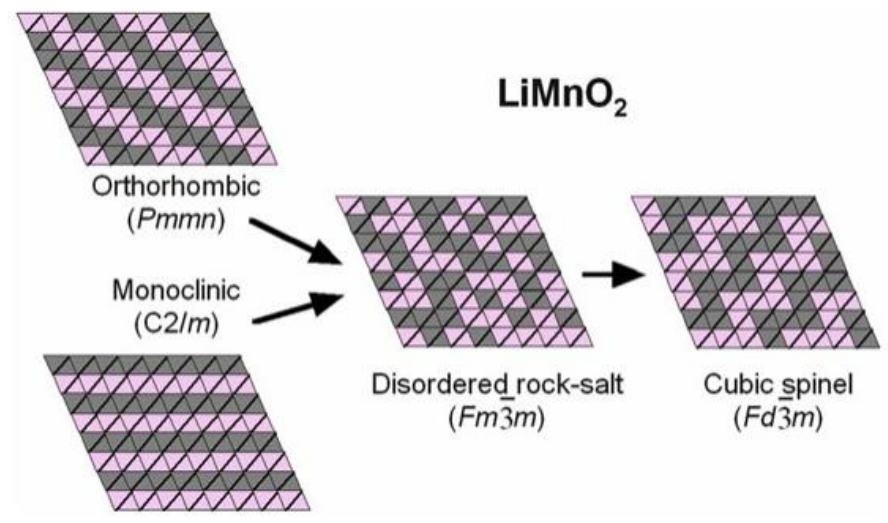

Fig. 3 Schematic representation of the structural transformation of orthorhombic $\mathrm{LiMnO}_{2}$ to spinel $\mathrm{LiMnO}_{2}$ phase during the cyclic voltammetry (Julien et al. 2015).

Different types of synthesis routes were used to obtain this material, including low temperature (Zhou et al. 2016), high temperature (Davidson et al. 1995), hydrothermal (Li et al. 2018c; and Xiao et al. 2009), flux method (Wenming et al. 2018), solid-state (Armstrong and Bruce 1996) and quenching (Lee and Yoshio 2001).

The work developed by Xiao's group (Xiao et al. 2009) reported that morphologies as rod and nanoparticles show different properties. The rods exhibit higher discharge

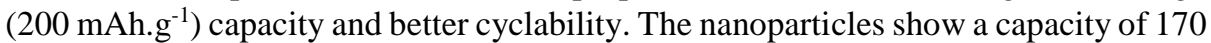
$\mathrm{mAh} . \mathrm{g}^{-1}$ but after 30 cycles it decreases to $110 \mathrm{mAh} . \mathrm{g}^{-1}$, whereas the rods decrease from $200 \mathrm{mAh} . \mathrm{g}^{-1}$ to $180 \mathrm{mAh} \cdot \mathrm{g}^{-1}$ after 30 cycles. The rod morphology plays an important role in the electrochemical performance once it favors the electron transport along the length pathway and accommodates the volume changes originated by the charge/discharge process.

In order to improve the cycle life of $\mathrm{LiMnO}_{2}$, coatings with cobalt oxide $(\mathrm{CoO})$ and alumina $\left(\mathrm{Al}_{2} \mathrm{O}_{3}\right)$ were realized. This improvement is due to the prevention of the $\mathrm{Mn}$ dissolution and lattice instability from the Jahn-Teller distortion (Cho et al. 2002; and Cho et al. 2001). Other methods as doping with Boron were also used to improve cycling performance of $\mathrm{LiMnO}_{2}$ batteries, in particular at high temperatures $\left(60{ }^{\circ} \mathrm{C}\right)$, by the reduction of surface reaction and/or transition metal dissolution. The improvement of the B-doping on the Coulombic efficiency ranges from $69.7 \%$ in pristine $\mathrm{LiMnO}_{2}$ to $99.0 \%$ in 10 at \% B-doped (Zhou et al. 2016). 


\subsubsection{Lithium manganese oxide $\left(\mathrm{LiMn}_{2} \mathrm{O}_{4}\right)$}

Lithium manganese oxide $\left(\mathrm{LiMn}_{2} \mathrm{O}_{4}\right)$ was proposed by Thackeray's group (Thackeray et al. 1984) in 1986 as the cathode material. This cathode corresponds to the third generation, with $\mathrm{LiCoO}_{2}$ representing the first and $\mathrm{LiFePO}_{4}$ representing the second. Composed by a transition metal oxide, $\mathrm{LiMn}_{2} \mathrm{O}_{4}$ is characterized by a space group fd $3 \mathrm{~m}(\mathrm{a}=8.2476-2)$, a density of $4.2 \mathrm{~g} \mathrm{~cm}^{-3}$, the $\mathrm{Li}$ and $\mathrm{Mn}$ occupying the tetrahedral (8a) and octahedral (16d) sites in the intervening cubic array of oxygen atoms (32e sites). The spinel structure shows a high lithium extraction ratio of $0.6\left(\mathrm{Li}_{1-}\right.$ $\left.{ }_{\mathrm{x}} \mathrm{Mn}_{2} \mathrm{O}_{4}, 0<\mathrm{x}<0.6\right)$ that provides a stable internal spinel structure and exhibits a

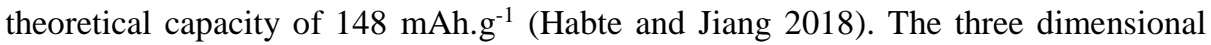
(3D) crystal structure allows also the 3D lithium diffusion (Momchilov et al. 1993), the electronic conductivity is about $10^{-4} \mathrm{~S} \mathrm{~cm}^{-1}$ (Ouyang et al. 2009) and the $\mathrm{Li}_{1-\mathrm{x}} \mathrm{Mn}_{2} \mathrm{O}_{4}$ $(0.27<\mathrm{x}<1)$ active material can be cycled at about $4 \mathrm{~V}$ vs lithium.

The main advantages of $\mathrm{LiMn}_{2} \mathrm{O}_{4}$ as a cathode in lithium batteries are the low-cost, low toxicity and thermal stability. The extra lithiation $\left(\mathrm{Li}_{2} \mathrm{Mn}_{2} \mathrm{O}_{4}\right)$ ensures a high amount of lithium ions insertion/extraction in the structure. Therefore, the theoretical capacity of this cathode is doubled as the number of charge carrier $\left(\mathrm{Li}^{+}\right)$is also double, with respect to $\mathrm{LiMn}_{2} \mathrm{O}_{4}$.

MacNeil group reported that $\mathrm{LiMn}_{2} \mathrm{O}_{4}$, when compared with $\mathrm{LiCoO}_{2}$ and $\mathrm{LiNiO}_{2}$ shows higher thermal stability at high temperature, when in contact with the electrolyte. This property shows that spinel $\mathrm{LiMn}_{2} \mathrm{O}_{4}$ suits to high power batteries (Ling et al. 2012).

On the other hand, the main obstacle to its commercialization is due to the fact that spinel $\mathrm{LiMn}_{2} \mathrm{O}_{4}$ shows significant capacity fading during the cycling and storage processes. This capacity fading at room and high temperatures are due to two main reason: 1) the manganese ( $\mathrm{Mn})$ dissolution into the electrolyte and 2) the Jahn-Teller instability caused by the ion $\mathrm{Mn}^{3+}$ at the octahedral sites (Ling et al. 2012). Further, at high voltages $(>4.3 \mathrm{~V})$ and elevated temperatures $\left(>55^{\circ} \mathrm{C}\right)$, the capacity fade also increase. Capacity degradation of this cathode is thus mainly originated by the dissolution of the $\mathrm{Mn}$ ions from the interface between cathode and electrolyte and its subsequent deposition on the anode surface that increases cell impedance (Chen et al. 2018).

The $\mathrm{LiMn}_{2} \mathrm{O}_{4}$ active material can be synthesized by different synthesis routes, such as: spray-drying (Wu et al. 2005), hydrothermal (Christiansen et al. 2016), coprecipitation (Thirunakaran et al. 2013), sol-gel (Zhang et al. 2018a) and solid-state (Yao et al. 2012), among others. Synthesis routes providing a fine particle size and uniform composition (such as sol-gel) leads to high electrochemical performance (Yi et al. 2009).

Efforts to overcome/improve the electrochemical problems and high-temperature performance include ions doping (Jiang et al. 2015), reducing particle sizes (Yi et al. 2009), different morphologies (Xia et al. 2012) and metal oxide coating (Chen et al. 2018). 
Yi et al. (Yi et al. 2009) synthesize spinel $\mathrm{LiMn}_{2} \mathrm{O}_{4}$ by adipic acid-assisted sol-gel and studied the influence of the synthesis temperature $\left(350,800\right.$ and $\left.900{ }^{\circ} \mathrm{C}\right)$ on phase formation and electrochemical activity (figure $4 \mathrm{a}-\mathrm{d}$ ). The results show that the samples calcinated at $800{ }^{\circ} \mathrm{C}$ show better ordering of the local structure, higher crystallinity, and lower lattice strain. Thus, it is possible to control the particle size by controlling the sintering temperature, the samples synthesized at $800{ }^{\circ} \mathrm{C}$ showing lower lattice defects, being the Mn chemical valence closer to 3.5.

Finally, nanoscale surface modifications have been investigated (Chen et al. 2018) (Fig. 4a). Xiao group (Xiao et al. 2018) evaluated the effect of morphology (porous and hollow) of $\mathrm{LiMn}_{2} \mathrm{O}_{4}$, obtained by precipitation synthesis using manganese cobalt $\left(\mathrm{MnCo}_{3}\right)$ (Fig. $\left.4 \mathrm{~b}\right)$ as template and manganese oxide $\left(\mathrm{MnO}_{2}\right)$ as intermediate (Fig. $\left.4 \mathrm{c}\right)$, in ion the electrochemical response of the cathode. It is concluded that the microspheres with a porous surface (Fig. 4e) exhibit a higher reversibility capacity and rate capability than the hollow surface sample (figure 4d). The current charge/discharge of the porous structure deliver a reversible capacity of $117.2 \mathrm{mAh} . \mathrm{g}^{-1}$ at $1 \mathrm{~A} . \mathrm{g}^{-1}$ and $92.1 \mathrm{mAh} . \mathrm{g}^{-1}$ at 10 A.g ${ }^{-1}$. 

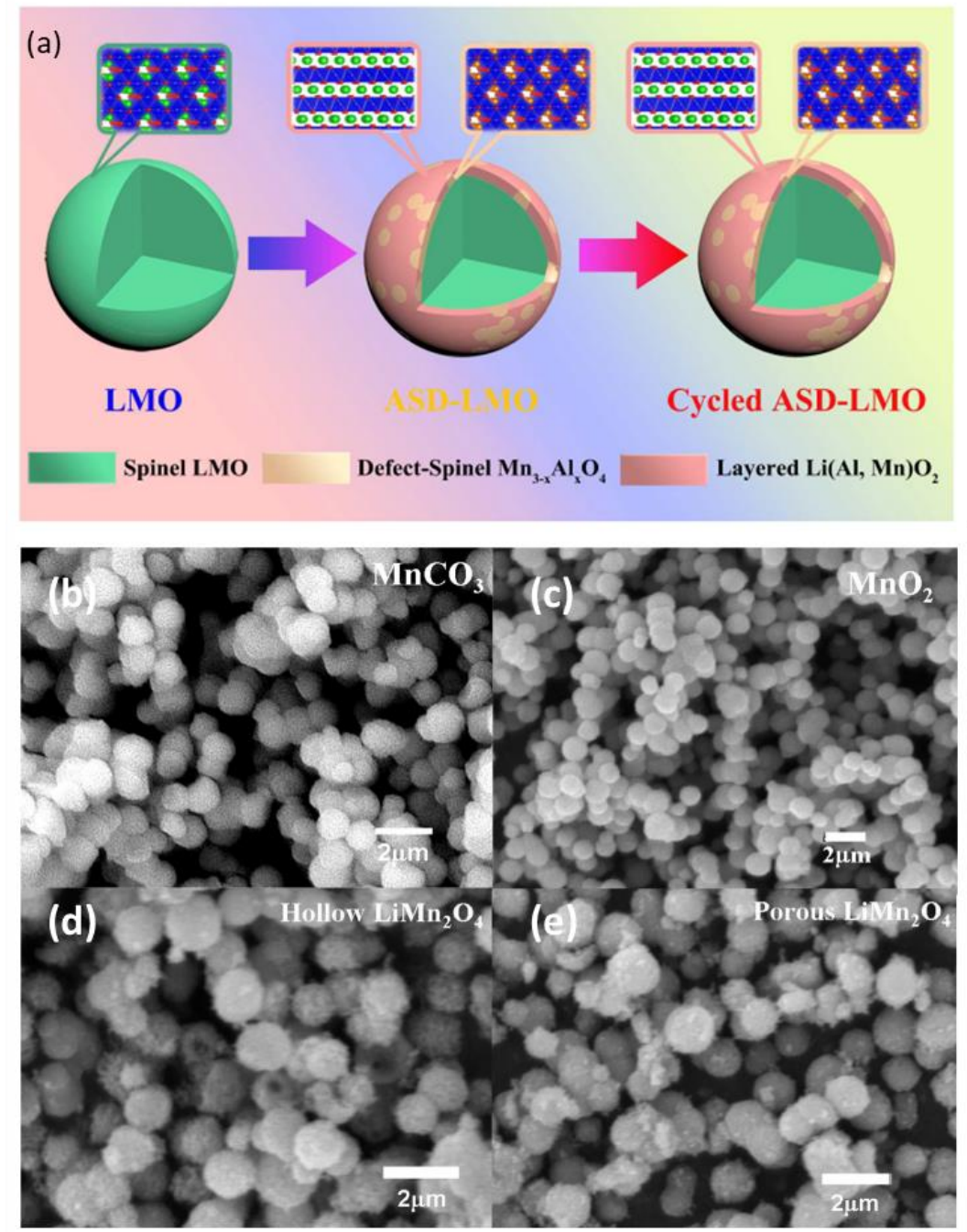

Fig. 4 a) Schematic representation of the surface modification of $\mathrm{LiMn}_{2} \mathrm{O}_{2}$ (Chen et al. 2018). $\mathrm{SEM}$ micrographs of the b) $\mathrm{MnCO}_{3}$ precursor, c) $\mathrm{MnO}_{2}$ intermediate, d) hollow $\mathrm{LiMn}_{2} \mathrm{O}_{4}$ microspheres and e) porous $\mathrm{LiMn}_{2} \mathrm{O}_{4}$ microspheres (Xiao et al. 2018).

\subsubsection{Lithium ferrous (II) phosphate ( $\left.\mathrm{LiFePO}_{4}\right)$}

Lithium ferrous (II) phosphate $\left(\mathrm{LiFePO}_{4}, \mathrm{LFP}\right)$ was first reported by Padhi's group (Padhi et al. 1997a). It is a member of the olivine family, crystalizes in the orthorhombic system with a Pnma $\left[\mathrm{D}_{2 \mathrm{~h}}\right]$ structure. Lithium ferrous (II) phosphate exhibits a distorted hexagonal-close-packed oxygen framework with lithium and iron located in half the octahedral sites and phosphorous ions located in one-eighth of the tetrahedral sites. The 
interatomic distances are $a=10.332(4) \AA, b=6.010(5) \AA$ and $c=4.692(2) \AA$ with a unit cell of 291.4(3) $\AA 3$ (Herle et al. 2004). The bulk $\mathrm{LiFePO}_{4}$ exhibits paramagnetic (form induced magnetic fields in the direction opposite to that of the applied magnetic field) behavior at room temperature (Wang et al. 2007b).

LFP has received a singular attention as cathode active material due to its ability to reach theoretical capacities of $170 \mathrm{mAh} \cdot \mathrm{g}^{-1}$ at moderate current densities and not generating oxygen under conditions such as electric overcharging and shortening (Julien et al. 2015).

The electrochemical extraction of lithium from the $\mathrm{LiFePO}_{4}$ active material gives $\left(\mathrm{Fe}^{2+} / \mathrm{Fe}^{3+}\right)$ redox potential at ca. $3.5 \mathrm{~V}$ vs. lithium, with reversible intercalation/deintercalation of one lithium per each $\mathrm{LiFePO}_{4}$. This active material has excellent cycling performance, the cubic lattice volume and crystal parameters slightly varying in this process, the volume variation during de lithium ion deintercalation decreasing by $6.81 \%$ and the density increasing by $2.59 \%$.

The advantages of this material are low-cost, iron abundance in nature, no memory effect, non-toxicity, resistance to overcharge, environmental friendliness, stable voltage plateau, and improved safety compared with cobalt oxides materials (Julien et al. 2015). Consequently, this active material is the first choice to use as a cathode in lithium batteries with medium-large capacity and medium-high power density.

Despite this, the intrinsically low electronic conductivity $\left(10^{-7}-10^{-9} \mathrm{~S} \mathrm{~cm}^{-1}\right)$ and low diffusion coefficient of lithium-ion $\left(10^{-11}-10^{-13} \mathrm{~cm}^{-2} \mathrm{~s}^{-1}\right)$ of bulk $\mathrm{LiFePO}_{4}$ result in capacity losses during the high-rate discharge. Further, comparing the olivine structure with the spinel and layered ones, the olive structure is less dense, leading to a lower volumetric energy density. The theoretical density of $\mathrm{LiFePO}_{4}$ is just $3.6 \mathrm{~g} \mathrm{~cm}^{-3}$ which is low compared with other materials such as $\mathrm{LiCoO}_{2}\left(5.1 \mathrm{~g} \mathrm{~cm}^{-3}\right)$ (Julien et al. 2015), but commercial $\mathrm{LiFePO}_{4}$ exhibits a density around $1.0-1.3 \mathrm{~g} \mathrm{~cm}^{-3}$, which shows that efforts should be taken to improve this material.

Different types of synthesis techniques were used to produce the $\mathrm{LiFePO}_{4}$ particles, including microwave (Yu et al. 2014), solid-state reaction (Rosaiah et al. 2017), template method (Liang et al. 2012), sol-gel (Ziolkowska et al. 2016), co-precipitation (Bai et al. 2015), hydrothermal (Vediappan et al. 2014) and mechanical activation (Wang et al. 2009), among others.

In order to enhance the electronic conductivity, different strategies such as the addition of carbon, surface treatment with carbon layers, substitution or doping and reduction of particle size, have been used.

The carbon used on the surface of $\mathrm{LiFePO}_{4}$ should be thin and not exceeding a few wt $\%$, with a thickness of around $3 \mathrm{~nm}$. With the surface treatment, the electronic conductivity of the active material could increase up to seven orders of magnitude. This carbon layer could be reached by the addition of organic materials as a carbon precursor and is limited to cathodes with low voltage response. In high voltage cathode materials, carbon will be electrochemically oxidized in the coating process and by the high applied potential in the charging process (Zhang and Zhang 2015). The carbon coating 1) provides, after deintercalation, electrons channels to balance the charge of active material; 2) increases the surface area of the active material due to the carbon nanometer-sized by the production of fine $\mathrm{LiFePO}_{4} ; 3$ ) avoids the production of $\mathrm{Fe}^{3+}$; 
4) prevents the polarization during the charge/discharge process; and 5) enhances the electronic conductivity (Liu et al. 2018; Wang and Sun 2015; and Wu 2015).

Nanostructured $\mathrm{LiFePO}_{4}$ has been produced in order to overcome some issues such as 1) the decrease to nano-size reduces the distances for the (de)intercalation of lithium ions, decreasing the capacity fading at high current density; 2) the increase of the surface area can increase the theoretical capacity and Coulombic efficiency due to the higher lithium quantity adsorbed on the surface; 3) increases the redox reaction interface; 4) ensures a bigger electrolyte immersion, among others ( Wu 2015).

\subsubsection{Lithium cobalt phosphate $\left(\mathrm{LiCoPO}_{4}\right)$}

Lithium cobalt phosphate $\left(\mathrm{LiCoPO}_{4}\right)$ is one of the most stable active material used as cathode due to its intrinsic properties and unique olivine structure with the orthorhombic system (Pnma, Z=8), lattice parameters $a=10.2048 \AA, b=5.9245 \AA$, and $c=4.7030 \AA$ and a density of $3.7 \mathrm{~g} \mathrm{~cm}^{-3}$. The redox potential of this material is $4.8 \mathrm{~V} \mathrm{vs}$ lithium and shows a flat voltage profile. With a theoretical capacity of $167 \mathrm{mAh} . \mathrm{g}^{-1}$, this active material also shows a small structural volume change (Choi et al. 2016).

This material has the advantage of exhibiting a high working potential compared with $\mathrm{LiFePO}_{4}$ and a larger theoretical performance compared with $\mathrm{LiCoO}_{2}$. On the other hand, the active material intrinsically exhibits poor rate capability, low lithium ion diffusion and low electronic conductivity $\left(<10^{-9} \mathrm{~S} \mathrm{~cm}^{-1}\right)$ due to the one-dimensional ion transport channel. The poor cyclability of this material is due to the oxidation of cobalt $\left(\mathrm{Co}^{2+}\right.$ to $\left.\mathrm{Co}^{3+}\right)$ and also by the decomposition of the carbonated electrolyte under charging between the 4.8 and $5.1 \mathrm{~V}$. This reaction contributes to low Coulombic efficiency and capacity fading during cycling.

The Pnma-LiCoPO 4 phase is the most explored by the scientific community but two more metastable $\mathrm{LiCoPO}_{4}$ phases, $\mathrm{Pna}_{1}\left[\mathrm{C}_{2 \mathrm{~V}}\right]$ and $\mathrm{Cmcm}\left[\mathrm{D}_{2 \mathrm{~h}}\right] \mathrm{LiCoPO}_{4}$, were discovered. These two phases, in contrast with Pnma $\left[\mathrm{D}_{2 \mathrm{~h}}\right]$, do not exhibit any significant electrochemical performance but both exhibit interesting magnetic properties, showing complex magnetic interactions at low temperatures that should be explored (Ludwig and Nilges 2018).

Different methods were used to synthesize this active material and to obtain different electrochemical performances (Fig. 5), including co-precipitation, microwave, mechanochemical, hydrothermal, solid-state (Karthickprabhu et al. 2014), spray drying and supercritical fluid, among others. 


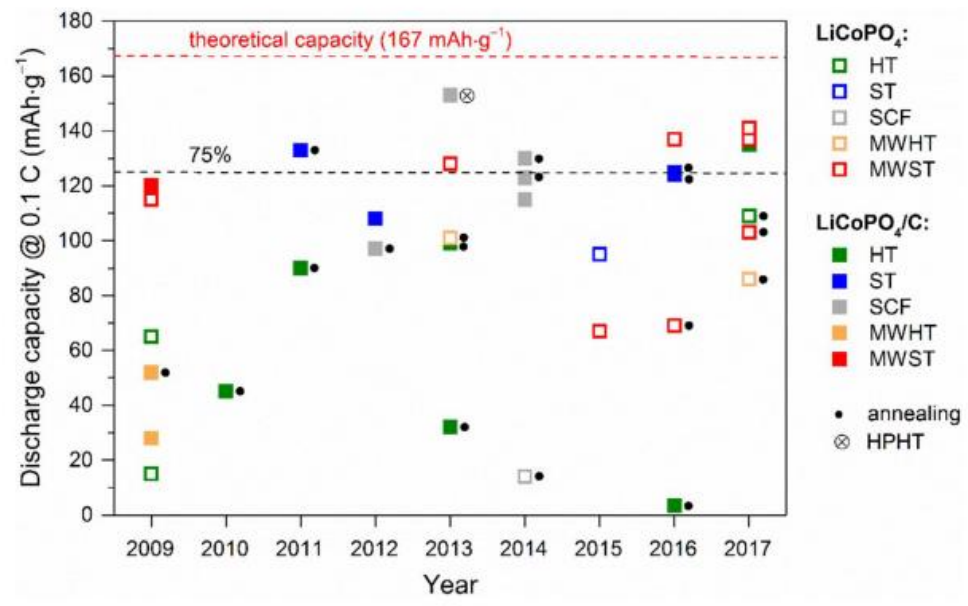

Fig. 5 Comparison of the initial discharge capacities at $0.1 \mathrm{C}$ reported for $\mathrm{LiCoPO}_{4}$ (white square) and $\mathrm{LiCoPO}_{4} / \mathrm{C}$ (black square) between 2009 and 2017, synthesized by different methods (Ludwig and Nilges 2018).

In order to form a stoichiometric $\mathrm{LiCoPO}_{4}$ without impurities, the precursor compounds used during the synthesis should have a strong Co-P bonding, preventing the formation of $\mathrm{Co}$ metal, lithium phosphate $\left(\mathrm{Li}_{3} \mathrm{PO}_{4}\right)$ and cobalt oxide $\left(\mathrm{Co}_{3} \mathrm{O}_{4}\right)$ phases (Choi et al. 2016). Further, the synthesis performed in an argon atmosphere and carbon addition improves the conductivity of $\mathrm{LiCoPO}_{4}$ (Wolfenstine 2006; and Wolfenstine et al. 2007).

To enhance the $\mathrm{LiCoPO}_{4}$ performance (increase electrical conductivity and rate capability) efforts in decreasing particle size (Wu et al. 2016), change morphology (Ludwig et al. 2017), carbon coating (Wu et al. 2018a) and lattice doping with supervalent metals ions (Kreder et al. 2016), have been made. In the Wang group approach. (Wang et al. 2010) it was shown that the addition of vanadium (V) improves the electrical conductivity of the active material around 5.3 times. Through carbon coating, different factors such as carbon source, thickness, homogeneity, and carbon content, influence the electrochemical performance.

The nanoflakes morphology was investigated by Hou group (Hou et al. 2018b) with the objective of enhancing the electrochemical performance of the $\mathrm{LiCoPO}_{4}$. The nanoflakes were coated with a thin carbon layer that orient the lithium ion transport channels. With this treatment, the aggregation of particles is avoided improving the stability of the electrode material. The carbon coating was obtained by the carbonization of 5-hydroxymethylfurfural $\left(\mathrm{C}_{6} \mathrm{H}_{6} \mathrm{O}_{3}\right)$ and levoglucosan $\left(\mathrm{C}_{6} \mathrm{H}_{10} \mathrm{O}_{5}\right.$, (1R,2S,3S,4R,5R)-6,8-dioxabicyclo[3.2.1] octane-2,3,4-triol) that further inhibit the growth of (010) facets that create more exposed lithium ion transport channels, also creating a conductive layer. 


\subsubsection{Lithium manganese phosphates $\left(\mathrm{LiMnPO}_{4}\right)$}

Lithium manganese phosphates $\left(\mathrm{LiMnPO}_{4}\right)$ crystallizes in an olivine structure with a density of $3.4 \mathrm{~g} \mathrm{~cm}^{-3}$ and, as all phospho-olivines structures, the oxygens ions are strongly bonded by covalent bonds with the phosphor $(+5)$ to form the $\mathrm{PO}_{4}{ }^{3+}$ tetrahedral polyanion stabilizing the framework. It exhibits an orthorhombic Pnma space group $\left[\mathrm{D}_{2 \mathrm{~h}}\right]$ and the typically crystallographic parameters are $a=6.106(1) \AA, b=10.452(1) \AA$, and $c=4.747(1) \AA$. With this structure stabilization, $\mathrm{LiMnPO}_{4}$ shows improved stability and safety for high operating voltage. Furthermore, manganese (Mn) and lithium (Li) occupy the octahedral $4 \mathrm{c}$ and $4 \mathrm{a}$ sites and the $\mathrm{P}$ atoms occupy the $4 \mathrm{c}$ sites. Comparing with lithium iron phosphate, $\mathrm{LiMnPO}_{4}$ draws the attention of the scientific community due to its higher theoretical energy density $\left(171 \mathrm{mAh} . \mathrm{g}^{-1}\right)$, higher operating voltage (4.1 V) and working within the stability window of the common non-aqueous electrolytes. Further, this cathode active material has advantages as low cost, environmentally friendlier nature, working ability at high temperatures and nontoxicity (Aravindan $e t$ al. 2013).

When compared with $\mathrm{Li}_{x} \mathrm{FePO}_{4}, \mathrm{Li}_{\mathrm{x}} \mathrm{MnPO}_{4}$ presents lower electrochemical performance. Furthermore, the $\mathrm{LiMnPO}_{4}$ active material exhibits low electronic conductivity $\left(<10^{-10} \mathrm{~S} \mathrm{~cm}^{-1}\right)$, relatively poor cycling stability (Jahn-Teller anisotropic lattice distortion and interface volume strain of $8.9 \%$ ) and weak lithium diffusion.

In order to overcome these negative properties, different methods and synthesis routes were applied to improve these drawbacks by the manipulation of its morphology/structure (Zhu et al. 2018a), cation distribution (Wu et al. 2018b) and electrochemical properties. Hydrothermal synthesis (Fujimoto et al. 2014), precipitation methods (Delacourt et al. 2004), solid-state reaction (Padhi et al. 1997b), template methods (Li et al. 2018a), sol-gel synthesis (Rajammal et al. 2016), electrospinning followed by calcination (Lu et al. 2014) and solvothermal reaction (Zhu et al. 2018a), among others, were used to prepare this active material.

To enhance the low intrinsic electronic conductivity methods such as decrease particle size, carbon coating, and cation doping, were explored. The nanoparticle approach is commonly used because with this method it is possible to improve the power rate and rate capability of the $\mathrm{LiMnPO}_{4}$ battery due to the reduction of $\mathrm{Li}^{+}$and electron length diffusion. The carbon coating on the $\mathrm{LiMnPO}_{4}$ surface enhances electronic conductivity by the reduction of particle agglomeration and by the formation of an effective conduction network between the layer and particle. Different carbon sources such as graphene and $\beta$-cyclodextrin $\left(\mathrm{C}_{42} \mathrm{H}_{70} \mathrm{O}_{35}\right.$, Heptakis(hydroxymethyl)tetradecaoxa-octa-cyclonona-tetracontane-tetradecol) were studied. The conductivity can be also improved by the doping with heterovalent and isovalent heteroatoms through the reduction of volume between the lithiation and delithiation phases. $\mathrm{LiMnPO}_{4}$ doping with transition metals is usually used because not only increases its conductivity but also increases or maintains its capacity. Lu group (Lu et al. 2014) studied doped $\mathrm{Mg}-\mathrm{LiMnPO}_{4}$ with fiber morphology (Fig. 6) and obtained a battery performance of $135 \mathrm{mAh} \cdot \mathrm{g}^{-1}$ at a $\mathrm{C} / 10$ rate $\left(15 \mathrm{mAh} \cdot \mathrm{g}^{-1}\right)$ that is superior to the one of $\mathrm{LiMnPO}_{4}$. 
a)

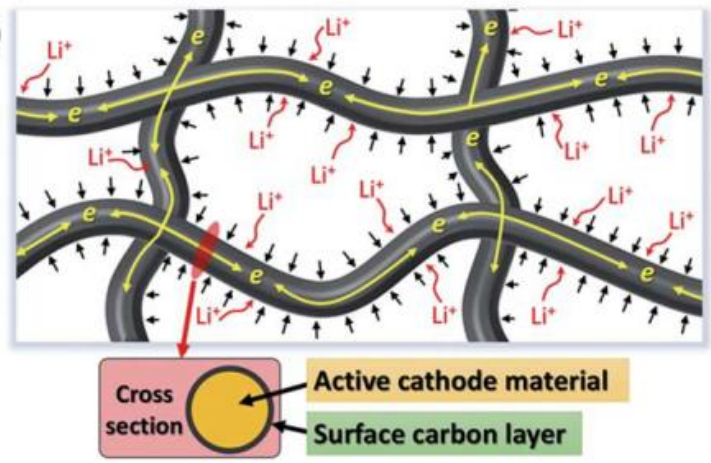

b)

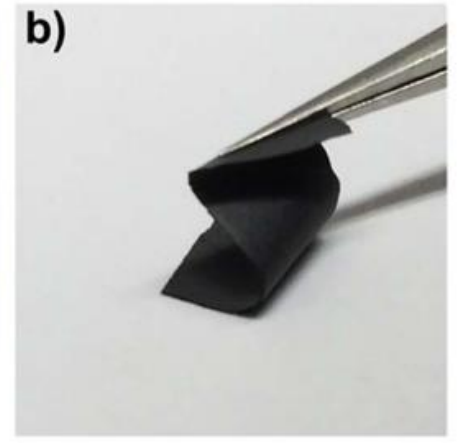

Fig. 6 a) Schematic diagram of $\mathrm{Mg}-\mathrm{LiMnPO}_{4}$ fibers and b) optical image of the flexibility of the fibers (Lu et al. 2014).

This sample shows a good cyclability without capacity fading during 200 cycles and the ability for being applied in flexible batteries. Li's team. (Li et al. 2018a) designed a $3 \mathrm{D}$ structure binder free $\mathrm{LiAlO}_{2}-\mathrm{LiMnPO}_{4} / \mathrm{C}$ cathode material with improvement in the electrochemical performance when compared with $\mathrm{LiMnPO}_{4} / \mathrm{C}$. The sample exhibits a capacity of $105 \mathrm{mAh} . \mathrm{g}^{-1}$ and $98.4 \%$ of capacity retention at a high discharge rate of $10 \mathrm{C}$, after 100 cycles. This structure can solve drawbacks such as the poor conduction of the active materials.

\subsubsection{Lithium nickel dioxide $\left(\mathrm{LiNiO}_{2}\right)$}

This active material is very attractive for being used in lithium-ion batteries due to higher discharge capacity ( 275 mAh.g $\left.{ }^{-1}\right)$, low cost (Yamada et al. 1995), higher potential (Fan 2004), small variation of unit cell volume (Ohzuku and Makimura 2006) and it is starting to be used in automotive application (Zhang and Wang 2009). The cell volume varies from 101 to $98.5 \AA 3$ in the composition range $0<\mathrm{x}<3 / 4$ for $\mathrm{Li}_{1-\mathrm{x}} \mathrm{NiO}_{2}$, which corresponds to about $2.5 \%$ shrinkage on oxidation (Ohzuku and Makimura 2006). The lithium ions diffusion of $\mathrm{LiNiO}_{2}$ is higher when the temperature increases and it is described by simple ion hopping with an activation energy of $0.6 \mathrm{eV}$ (Nakamura et al. 2000). Some disadvantages of this material are the low capacity retention and thermal stability (Zhu et al. 2006). As for the other active materials, the morphology and particle size influence the cycling performance of $\mathrm{LiNiO}_{2}$ (Sheu et al. 1997), smaller particles showing higher capacity, but larger particles providing higher thermal stability (Li et al. 1997). At room temperature, the electrical resistivity of this material is $4 \Omega \cdot \mathrm{cm}^{-1}$ (Migeon et al. 1978). Due to the nickel (Ni) element, this active material shows magnetic properties, the antiferromagnetic phase (the magnetic moments related to the spins of electrons, align in a regular pattern with neighboring spins pointing in opposite directions) increasing in contact with the ferrimagnetic (whose strength depends on that of the applied magnetizing field, and which may persist after removal of the applied field) with nickel/lithium $\mathrm{Ni} / \mathrm{Li}$ defect $\mathrm{LiNiO}_{2}$ due to 
increasing Li content (Thirunakaran et al. 2013). Its electrochemical window, surface energy, and morphology were theoretically studied within the density functional theory (DFT) framework and it was observed that tetragonal $(t)$ Li-terminated surfaces are characterized by lower surface energies than those of the oxygen surfaces irrespective of facet direction. Further, Ni-exposed surfaces are the least stable (Cho et al. 2017). Also, this theory was used for studying the effect of non-stoichiometry (extra-Nidefects) on the electrochemical performance of Ni-rich layered oxides and it was verified that extra-Ni-defects trigger a charge disproportionation reaction that reduces the Jahn-Teller distortion (Kong et al. 2018).

One simple synthesis of this structure is by heating a mixture of hydrated lithium hydroxide $\left(\mathrm{LiOH}_{2} \mathrm{H}_{2} \mathrm{O}\right)$ and nickel (II) hydroxide, $\mathrm{Ni}(\mathrm{OH})_{2}(\mathrm{Li} / \mathrm{Ni}=1.1 / 1$ in molar ratio) in the range from 500 to $900{ }^{\circ} \mathrm{C}$ for $5 \mathrm{~h}$ in air or oxygen. It was observed that the structure prepared in an oxygen atmosphere at $700{ }^{\circ} \mathrm{C}$ exhibits the highest discharge capacity of $200 \mathrm{mAh.g}{ }^{-1}$ in the voltage range from 3.0 to $4.3 \mathrm{~V}$ and the charge-transfer resistance is related to the structural transformation of $\mathrm{Li}_{1-\mathrm{x}} \mathrm{NiO}_{2}, 0.15<\mathrm{x}<0.75$ (Yamada et al. 1995). Different lithium precursors have been used for obtaining this compound, Lithium nitrate $\left(\mathrm{LiNO}_{3}\right)$ (Molenda et al. 2002; and Moshtev et al. 1995), LiOH. $\mathrm{H}_{2} \mathrm{O}$ (Song et al. 2014), $\mathrm{Li}_{2} \mathrm{CO}_{3}$ (Wang and Navrotsky 2004), as well as different synthesis methods, such as coprecipitation (Sasaki et al. 2009), emulsion (Kim et al. 2007), combustion (Rao et al. 2001), solid state (Song et al. 2014; and Sun et al. 2006a) and nanoscale $\mathrm{MnCO}_{3}$ treatment (Zhao et al. 2017), among others.

In order to improve its thermal stability and consequently battery performance, different coatings with cobalt (Co) and manganese (Mn) (Deng et al. 2008), $\mathrm{SiO}_{2}$ (Mohan and Paruthimal Kalaignan 2013) and Vanadium(V) oxide $\left(\mathrm{V}_{2} \mathrm{O}_{5}\right)$ (Xiong et al. 2014) were carried out. The coating layer of $\mathrm{Co}$, Mn particles improved the electrochemical properties of lithium nickel dioxide $\left(\mathrm{LiNiO}_{2}\right)$ through decreasing the impedance growth at the interface between the electrodes/electrolyte during battery cycling (Deng et al. 2008). It has been shown that silica $\left(\mathrm{SiO}_{2}\right)$ coating at $2 \mathrm{wt} . \%$ leads to high structural stability and reversible capacity (Mohan and Paruthimal Kalaignan 2013) and that a $\mathrm{V}_{2} \mathrm{O}_{5}$-coating layer works as hydrogen fluoride (HF) inhibitor and/or HF scavenger (from in-situ precipitated cathode surface), which contributes to a significant improvement in cycling performance and storage characteristics in electrolyte (Xiong et al. 2014).

Also for improving the electrochemical properties, this compound has been doped with iron (Guo et al. 2004), cobalt and manganese (Muto et al. 2012; and Zheng et al. 2016), aluminum (Liu et al. 2011b), cerium (Mohan et al. 2012). Further, a novel inorganic nitrate salt synthesis was proposed (Guo et al. 2004).

The emulsion method has been used to synthesize this compound and the optimal conditions for this synthesis were $750^{\circ} \mathrm{C}$ and $24 \mathrm{~h}$ in an oxygen stream, as represented in Fig. 7 (Kim et al. 2007). 

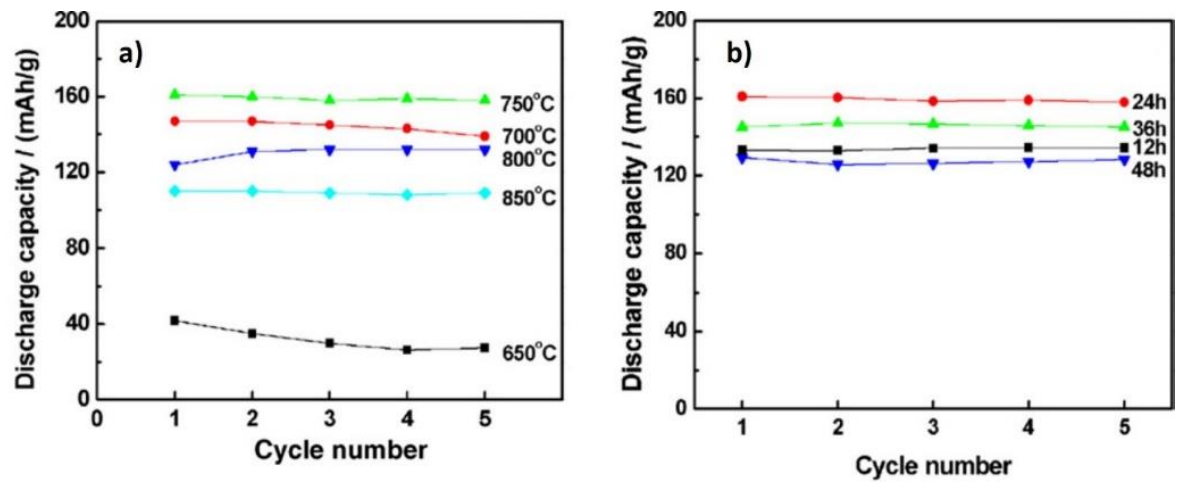

Fig. 7 Discharge capacity as a function of cycle number for $\mathrm{LiNiO}_{2}$ powders: a) at various temperatures for $24 \mathrm{~h}$ and b) at $750{ }^{\circ} \mathrm{C}$ for various times (Kim et al. 2007).

Aluminum doping in $\mathrm{LiNiO}_{2}$ reduces lithium deficiency, stabilizes the crystal structure and improves electrochemical cycling (Liu et al. 2011b). The doping of cerium leads to high Coulombic efficiency, high electrical conductivity and low irreversible capacity loss (Mohan et al. 2012).

Surface modification of $\mathrm{LiNiO}_{2}$ was also achieved by the addition of titania $\left(\mathrm{TiO}_{2}\right)$ or zinc (II) oxide ( $\mathrm{ZnO})$ and it was observed a decrease in the discharge capacity, but improved cycling performance (Song et al. 2014).

\subsubsection{Lithium Nickel Cobalt oxide $\left[\mathrm{LiNi}_{1-\mathrm{x}} \mathrm{Co}_{\mathrm{x}} \mathrm{O}_{2}(0.2 \leq \mathrm{x} \leq 0.5)\right]$}

This active material results from the combination of lithium cobalt oxide $\left(\mathrm{LiNiO}_{2}\right)$ and lithium cobalt oxide $\left(\mathrm{LiCoO}_{2}\right)$, the addition of cobalt into $\mathrm{LiNiO}_{2}$ improving the thermal stability and cycling performance (Delmas and Saadoune 1992), as well as the delivered capacity, due to the stabilization of the structure with respect to $\mathrm{LiCoO}_{2}(\mathrm{Li}$ and Currie 1997; Rougier et al. 1996). Considering the enthalpy of formation of this active material, the cobalt compound is significantly more stable than the nickel analog (Wang and Navrotsky 2004). The magnetic properties of this material have been studied indicating the existence of randomly oriented magnetic moments even at $2 \mathrm{~K}$, i.e., a disordered state (Mukai et al. 2007).

Different methods have been used for synthesizing these particles, such as, sol-gel (Fonseca et al. 2006; Moses et al. 2007), solid-state reaction (Kang et al. 2004), heattreatment (Kinoshita et al. 2001), co-precipitation and rheological phase reaction (Li et al. 2008), rheological phase reaction (Wang et al. 2007a) and gel-combustion (Wu et al. 2003a), among others.

It was demonstrated that $\mathrm{LiNi}_{1-\mathrm{x}} \mathrm{Co}_{\mathrm{x}} \mathrm{O}_{2}(0.1<\mathrm{x}<0.3)$ shows a low capacity fade rate when compared to that of $\mathrm{LiCoO}_{2}$, being suitable for commercial batteries ( $\mathrm{Li}$ and Currie 1997).

Novel synthesis methods -co-precipitation and rheological phase reaction methodwas successfully used for this active material in which the calcination temperature effects on the electrochemical performance (Li et al. 2008), and Wang et al. 2007a). 
This active material was used as a coating for lithium manganese oxide $\left(\mathrm{LiMn}_{2} \mathrm{O}_{4}\right)$ to improve its thermal and electrochemical properties, which is ascribed to the suppression of electrolyte decomposition and the reduction of Mn dissolution (Park et al. 2002).

\subsubsection{Lithium Nickel Manganese Cobalt Oxide $\left(\mathrm{LiNi}_{1 / 3} \mathrm{Mn}_{1 / 3} \mathrm{Co}_{1 / 3} \mathrm{O}_{2}\right)$}

Lithium nickel manganese cobalt oxide $\left(\mathrm{LiNi}_{1 / 3} \mathrm{Co}_{1 / 3} \mathrm{Mn}_{1 / 3} \mathrm{O}_{2}\right)$ is a very promising active material as a cathode electrode, begin used in electric vehicles applications (Blomgren 2017) and semi-solid flow batteries (Jacas et al. 2016). It shows higher capacity and tap density and better thermal stability, lower cost, less toxicity and safety in comparison to other active materials (Han et al. 2010). Recently, it was demonstrated that it can be used also for anode electrodes (Wang et al. 2018). The magnetic properties of the material were evaluated and it was verified that both frustration and disorder play important roles in the formation of a spin glass state (Bie et al. 2013). In order to investigate the changes in its crystal-structure stability, calculations were carried out through by the discrete variational (DV)-X $\alpha$ molecular orbital method based on the selfconsistent Hartree-Fock-Slater model compounds. Using known symmetries $\left(\mathrm{C}_{3 \mathrm{v}}\right)$ the radial function for molecular orbitals of model cluster atoms method is used to compute the energies in the order of the transition metal layer affecting the charge-discharge cycle characteristics (Karino 2016). For this compound, Ni participates act a redox species and change from $4^{+}$to $2^{+}$during charging. Further, $\mathrm{Ni}^{4+}$ becomes Jahn-Teller active $\mathrm{Ni}^{3+}$ at intermediate states during charge and Mn (Mogi et al. 2013). The analysis with in situ Auger electron spectroscopy and X-ray photoelectron spectroscopy of this compound during charging and overcharging shows that $\mathrm{Mn}$ is redox active below $\sim 4.3$ $\mathrm{V}$ and that $\mathrm{O}$ becomes redox active above $\sim 4.2 \mathrm{~V}$. Ni and Co also participate in surface redox (Tang et al. 2018). Typically, the diffusion coefficient is in the range $10^{-11}-10^{-12}$ $\mathrm{cm}^{2} . \mathrm{s}^{-1}$ (Zhang et al. 2011b).

The analysis of overpotentials in this active material shows that the characteristic overpotentials during charge (delithiation) and discharge (lithiation) are state of charge (SOC) and depth of discharge (DOD) dependent, respectively (Kasnatscheew et al. 2016). It was also demonstrated that the specific capacity fades during cycling at constant specific currents can be mainly attributed to the increase of the delithiation (charge) hindrance (Kasnatscheew et al. 2017).

This active material presents poor electronic conductivity that affects its electrochemical performance and, therefore, different approaches have been used to improve its electric and ionic conductivity, including adding graphene, which decreases the charge-transfer resistance (Venkateswara Rao et al. 2011), developing composition between this active material and lithium phosphor sulfur $\left(\mathrm{Li}_{3} \mathrm{PS}_{4}\right)$ (Asano et al. 2017), co-coating (Dang et al. 2017), coating with lithium boron oxide glass (Dou et al. 2012) and carbon nanotubes /graphene (CNT/G) (Li et al. 2017c).

In all-solid-state batteries, the interface between the active material and solid electrolyte is essential for obtaining high ionic conductivity, and this interface was studied for Argyrodite $\left(\mathrm{Li}_{6} \mathrm{PS}_{5} \mathrm{Cl}\right)$, demonstrating that the oxidation processes of the solid electrolyte do not hinder the good cyclability of the battery (Auvergniot et al. 2017). 
Several experimental techniques have been used for synthesizing this compound such as redox synthesis (Baboo et al. 2017), co-precipitation (Bie et al. 2013; Cabelguen et al. 2017; and He et al. 2018), solid-state reaction (Cui et al. 2018; and Kageyama et al. 2006), heating (Fujii et al. 2007), pre-sintering (Han et al. 2018), convenient rheological phase reaction (Han et al. 2010; Peng et al. 2015; and Ren et al. 2008), microwave pyrolysis (Han et al. 2013), sol-gel (Hashem et al. 2013), chemical vapor deposition (Hou et al. 2018a), polyol medium (Li et al. 2014), spray dry (Li et al. 2006b), using manganese(II) carbonate $\left(\mathrm{MnCO}_{3}\right)$ both as a self-template and $\mathrm{Mn}$ source (Li et al. 2013a), acetic acid $\left(\mathrm{C}_{2} \mathrm{H}_{4} \mathrm{O}_{2}\right)$ leaching and maleic acid $\left(\mathrm{C}_{4} \mathrm{H}_{4} \mathrm{O}_{4}\right.$, cisbutenedioic acid) leaching ( $\mathrm{Li}$ et al. 2018b), Pechimi method (Samarasingha et al. 2008), nitrate-melt decomposition (Sathiya et al. 2009), microwave-mediated hydrothermal (Shen et al. 2008), high temperature ball milling (Tian 2017), hydrothermal ( $\mathrm{Wu}$ et al. 2010), mechanochemical activation ( $\mathrm{Xu}$ et al. 2018), combustion (Zeng et al. 2018), sacrificial template (Zhang et al. 2017) and combining coprecipitation with the hydrothermal method (Zheng et al. 2017).

The preparation of this compound through the Pechini method allows reducing calcination times and minimal lithium evaporation (Samarasingha et al. 2008).

In the combustion method, it was studied the effect of the addition of triethanolamine (TEA, $\mathrm{C}_{6} \mathrm{H}_{15} \mathrm{NO}_{3}$ ) in the synthesis, showing that synthesis with TEA exhibits lower polarization, better cycling ability and significantly improved rate performance (Zeng et al. 2018).

It has been shown that different carbonate precipitators affect its synthesis and consequently battery performance, the best discharge capacity value being obtained for sodium bicarbonate $\left(\mathrm{NaHCO}_{3}\right)$ (Ren et al. 2009).

A new synthesis process based on the sodium carbonate $\left(\mathrm{Na}_{2} \mathrm{CO}_{3}\right)$ coprecipitation method was developed for this active material. The obtained morphology and elemental distribution are shown in Fig. 8a) (He et al. 2018). It has been also shown that using $\mathrm{Na}_{2} \mathrm{CO}_{3}$ as a precipitant improves the electronic conductivity of the electrode, which contributes to improved rate capability (Zheng et al. 2016). Calcium carbonates $\left(\mathrm{CaCO}_{3}\right)$ template was also used for the synthesis of this active material (Zhang et al. 2015).

The chemical vapor deposition (CVD) method with sucrose as a source of carbon for the coating of this active material was developed, allowing better uniformity, higher quality and better electrochemical performance in comparison to the thermal evaporation method (Hou et al. 2018a).

Nanoplates of this active material with exposed [010] active facets were synthesized in a polyol medium (ethylene glycol, EG, $\mathrm{C}_{2} \mathrm{H}_{6} \mathrm{O}_{2}$ ) and these facets can lead to more channels for $\mathrm{Li}^{+}$-ion migration, resulting in an improvement in their electrochemical performance (Li et al. 2014).

The impact of the different morphologies on the electrochemical performance was studied, in which highly dense materials exhibit the best power performances in terms of volumetric figures as shown in Fig. 8b) (Cabelguen et al. 2017). 

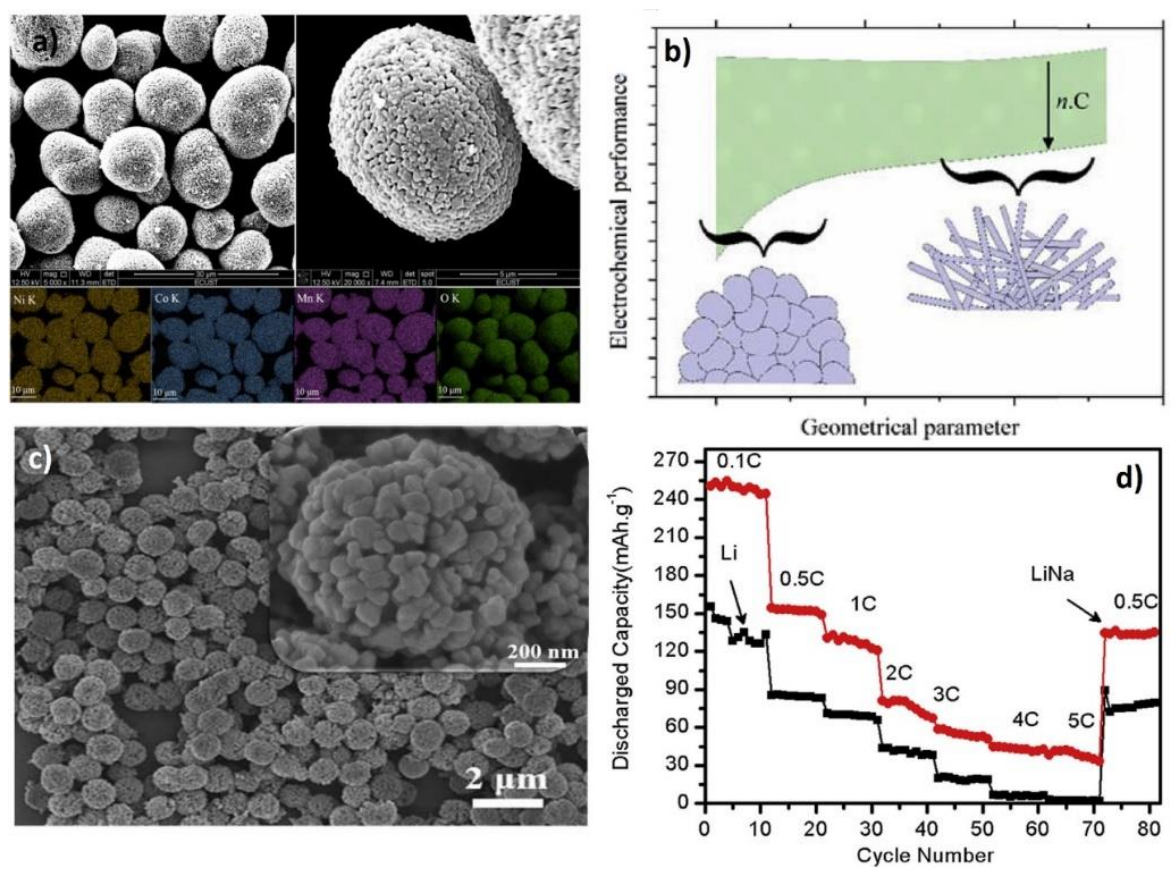

Fig. 8 a) SEM-EDS analysis and elemental maps of this compound (He et al. 2018), b) Different morphologies versus electrochemical performance (Cabelguen et al. 2017) and c) SEM image of xLi2MnO3.(1-x)LiNi1/3Co1/3Mn1/3O2 microspheres (Li et al. 2016) and d) Cycling performance of this active material doped with $\mathrm{Na}$ element (Gong et al. 2014).

$\mathrm{xLi}_{2} \mathrm{MnO}_{3 .(1-\mathrm{x})} \mathrm{LiNi}_{1 / 3} \mathrm{Co}_{1 / 3} \mathrm{Mn}_{1 / 3} \mathrm{O}_{2}(\mathrm{x}=1 / 4,1 / 3$, and 1/2) hollow microspheres have been fabricated (Fig. 8c) with high specific capacity and capacity retention for $\mathrm{x}=1 / 3$ (Li et al. 2016). Further, $\mathrm{xLi}_{2} \mathrm{MnO}_{3 .(1-x)} \mathrm{LiNi}_{1 / 3} \mathrm{Co}_{1 / 3} \mathrm{Mn}_{1 / 3} \mathrm{O}_{2}$ was also synthesized by the molten-salt method and, in this case, $\mathrm{x}=0.4$ presents better electrochemical performance (Yuan et al. 2016).

Structural stability and consequently battery performance by reducing capacity fade have been improved by doping/modifying with different elements such as sodium (Na) (Chen et al. 2014a; Gong et al. 2014; and Li et al. 2017d) as illustrated in Fig. 8d), aluminum (Al) and iron (Fe) (Liu et al. 2006a), silicon ( $\mathrm{Si}$ ) (Na et al. 2005), phosphate $\left(\mathrm{PO}_{4}\right)^{3-}$ (Cong et al. 2016), chromium(III) oxide $\left(\mathrm{Cr}_{2} \mathrm{O}_{3}\right)$ ( $\mathrm{He}$ et al. 2017), $\mathrm{ZrO}_{2}$ ( $\mathrm{Hu}$ et al. 2009), lanthanum oxide $\left(\mathrm{La}_{2} \mathrm{O}_{3}\right)$ (Jiang et al. 2018; Sun et al. 2018), alumina $\left(\mathrm{Al}_{2} \mathrm{O}_{3}\right)$ (Kim et al. 2006; Peng et al. 2008), titania $\left(\mathrm{TiO}_{2}\right)$ ( $\mathrm{Li}$ et al. 2006a), aluminium phosphate $\left(\mathrm{AlPO}_{4}\right)$ (Li et al. 2017a), manganese oxide $\left(\mathrm{MnO}_{\mathrm{x}}\right)$ (Xiong et al. 2014), lithium manganese oxide $\left(\mathrm{LiMn}_{2} \mathrm{O}_{4}\right)$ (Yan et al. 2015), zirconia $\left(\mathrm{ZrO}_{2}\right)$ (Yano et al. 2016), fluoroborate glass ( $\mathrm{MO}-\mathrm{MF}_{2}-\mathrm{B}_{2} \mathrm{O}_{3}$, where $\mathrm{M}=$ metal like $\mathrm{Pb}$ ) (Qibing et al. 2017), lithium titanium phosphate $\left[\mathrm{LiTi}_{2}\left(\mathrm{PO}_{4}\right)_{3}\right]$ (Zhang et al. 2018b) and europium (III) oxide $\left(\mathrm{Eu}_{2} \mathrm{O}_{3}\right)$ ( $\mathrm{Zhu}$ et al. 2016) coatings. These different coatings also suppress the increase of charge transfer resistance (Rct). Improved performance has been also achieved in cathode composites of this active material with lithium iron phosphate 
$\left(\mathrm{LiFePO}_{4}\right)$ (Liu et al. 2014), vanadium(V) oxide $\mathrm{V}_{2} \mathrm{O}_{5}$ to improve electrochemical performance (Meng et al. 2018), lithium manganese oxide $\left(\mathrm{LiMn}_{2} \mathrm{O}_{4}\right)$ to improve rate capability (Nam et al. 2009), lithium vanadate $\left(\mathrm{LiVO}_{3}\right)$ (Onodera et al. 2017) and polypyrrole (PPy, $\left.\left[\mathrm{C}_{4} \mathrm{H}_{2} \mathrm{NH}\right)\right]_{\mathrm{n}}$ ) (Zhang et al. 2011a).

Beyond improvements in the active material, scientific advances have been achieved in the electrode slurry by using water in its production. Thus, for this compound, $\gamma$ alumina $\left(\mathrm{Al}_{2} \mathrm{O}_{3}\right)$ or silica $\left(\mathrm{SiO}_{2}\right)$ significantly enhance the electrode performance of the water-based cathode (Memm et al. 2018) as well as new binders such as polyacrylic latex (Zhong et al. 2016).

\subsubsection{Lithium Nickel Manganese Oxide $\left(\mathrm{LiNi}_{0.5} \mathrm{Mn}_{0.5} \mathrm{O}_{2}\right)$}

Lithium nickel manganese oxide $\left(\mathrm{LiNi}_{0.5} \mathrm{Mn}_{0.5} \mathrm{O}_{2}\right)$ shows a high theoretical capacity of $280 \mathrm{mAh} \cdot \mathrm{g}^{-1}$ and it is also inexpensive, nontoxic, shows thermal stability and cycle life being a possible alternative to $\mathrm{LiCoO}_{2}$ (Meng et al. 2008). It shows some disadvantages such as substantial $\mathrm{Li} / \mathrm{Ni}$ disorder, poor intrinsic rate capability and structural impurity (Kang et al. 2006). The oxidation states of the transition metals in this active material are $\mathrm{Mn}^{4+}$ and $\mathrm{Ni}^{2+}$ in which their structure and unit cell are shown in Fig. 9 (Deb et al. 2006).

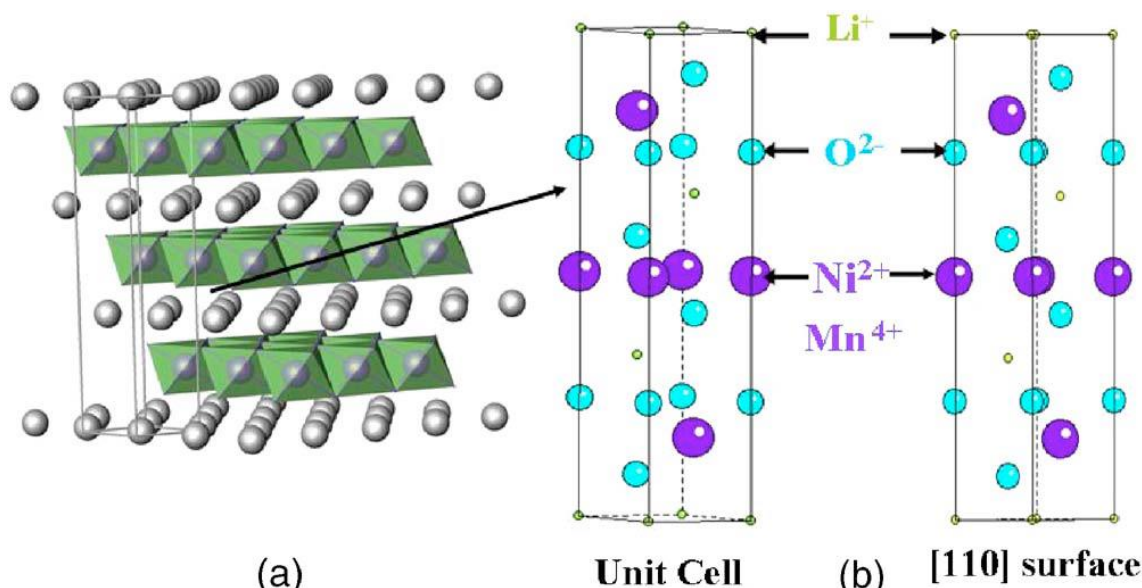

Fig. 9 a) Structure and b) unit cell of $\mathrm{LiNi}_{0.5} \mathrm{Mn}_{0.5} \mathrm{O}_{2}$ (Deb et al. 2006).

It has been observed on delithiation of $\mathrm{Li}_{1-x} \mathrm{Ni}_{0.5} \mathrm{Mn}_{0.5} \mathrm{O}_{2}$ that $\mathrm{Mn}$ is electrochemically inactive and remains at $\mathrm{Mn}^{4+}$ whereas the $\mathrm{Ni}$ is oxidized from $\mathrm{Ni}^{2+}$ to almost $\mathrm{Ni}^{4+}$ through an intermediate stage of $\mathrm{Ni}^{3+}$ (Deb et al. 2006).

The relative energy positions and shape of the density of states of $\mathrm{O}_{2 \mathrm{p}}$ and $\mathrm{Ni}_{3 \mathrm{~d}}$ have been investigated for this active material and it was verified that $\mathrm{O}_{2 p}$ electrons are itinerant and exist in the vicinity of the Fermi energy more than $\mathrm{Ni}_{3 \mathrm{~d}}$ electrons (Satou et al. 2017). 
The electrode/electrolyte interface of this active material was investigated and after one electrochemical cycle, it is demonstrated the strong influence of the variation of potential (Dupré et al. 2009).

Lithium nickel manganese oxide $\left(\mathrm{LiNi}_{0.5} \mathrm{Mn}_{0.5} \mathrm{O}_{2}\right)$ has been synthesized by different methods such as solid solution (Meng et al. 2008), freeze drying (Shlyakhtin et al. 2004), in situ conversion route (Liu et al. 2011a), co-precipitation (Dou and Li 2014) (B. et al. 2006), combination of hydroxide and molten-salt methods (Jeong et al. 2005), wet chemical (Sun et al. 2016a), solid-state reaction (Wu et al. 2003b), hydrothermal method (Zhao et al. 2014) and ultrasonic irradiation in co-precipitation method (Zhang et al. 2007).

For the co-precipitation method, a morphology composed of hexagonal cubes was obtained, which improves the electrochemical performance (Dou and Li 2014).

The synthesis of this active material through of ball milling was proposed, leading to materials with very small capacity fading (Xia et al. 2008). This structure was doped with fluorine $(\mathrm{F})$ element to reduce cation mixing and improve the poor rate performance (Hu et al. 2013). The same was observed by ruthenium (Ru) doping of $\mathrm{LiNi}_{0.5} \mathrm{Mn}_{0.5} \mathrm{O}_{2}$ (Sun et al. 2016a).

Composites of $\mathrm{LiNi}_{0.5} \mathrm{Mn}_{0.5} \mathrm{O}_{2}$ with lithium cobalt oxide $\left(\mathrm{LiCoO}_{2}\right)$ and lithium manganese oxide $\left(\mathrm{Li}_{2} \mathrm{MnO}_{3}\right)$ were prepared by spray drying in which the discharge capacity increases with increasing cobalt (Co) content (Sun et al. 2006b). Similarly, a composite cathode with lithium manganese alumina $\left(\mathrm{LiMn}_{1.9} \mathrm{Al}_{0.1} \mathrm{O}_{4}\right)$ was developed, leading to the improvement in the electrochemical performance through structural stabilization (Tian et al. 2016).

\subsubsection{Lithium vanadium oxide $\left(\mathrm{LiV}_{2} \mathrm{O}_{5}\right)$}

Lithium vanadium oxide $\left(\mathrm{LiV}_{2} \mathrm{O}_{5}\right)$ has the advantages of higher energy density ( 450 Wh. $\mathrm{kg}^{-1}$ ) (Delmas et al. 1991), long cycle and low environmental impact, but it has as a disadvantage a high capacity fading resulting from structural modifications ( Baddour-Hadjean et al. 2012). Their structure was reported to be the space group Pna 21 $\left[\mathrm{C}_{2 \mathrm{~V}}\right]$ but refined in $\mathrm{Pn} 2_{1}$ a where the $\mathrm{Li}$ atom has a crude octahedral coordination with one distance [to 0(6)] considerably lower than the others (Anderson and Willett 1971).

The electronic properties of $\alpha-\mathrm{Li}_{\mathrm{x}} \mathrm{V}_{2} \mathrm{O}_{5}$ ( $\mathrm{x}=0.5$ and 1 ) were investigated through density functional theory (DFT) in which the intercalation of Li into $\mathrm{V}_{2} \mathrm{O}_{5}$ does not change the electron transition property of $\mathrm{V}_{2} \mathrm{O}_{5}$, which is an indirect band gap semiconductor ( $\mathrm{Li}$ and $\mathrm{Wu} 2008)$.

The $\omega$-phase of $\mathrm{LiV}_{2} \mathrm{O}_{5}$ consists in the stability of its tetragonal structure $(\Delta \mathrm{V} / \mathrm{V}<$ $1 \%)$ as the $\mathrm{Li}$ insertion extraction proceeds and, at a higher rate above of $\mathrm{C} / 5$, the capacity decreases through a significant dissolution process of the vanadium oxide, leading to the presence of $\mathrm{V}^{4+}$ and $\mathrm{V}^{3+}$ species in the electrolyte (Leger et al. 2005).

Through NMR spectra of the fully discharged $\mathrm{Li}_{\mathrm{x}} \mathrm{V}_{2} \mathrm{O}_{5}$ cathode, it is observed a changing of $\mathrm{V}$ ion from $\mathrm{V}^{+5}$ to $\mathrm{V}^{+4}$. The lithium intercalated $\mathrm{Li}_{\mathrm{x}} \mathrm{V}_{2} \mathrm{O}_{5}$ system has been studied using ab initio calculations in which different phases were obtained during the reaction ((omega) $\omega-\mathrm{Li}_{3} \mathrm{~V}_{2} \mathrm{O}_{5}$ and (zeta) $\zeta-\mathrm{Li}_{2} \mathrm{~V}_{2} \mathrm{O}_{5}$ ) (Rocquefelte et al. 2003). For 
intercalation amounts larger than one, the (delta) $\delta$-phase is transformed into a (gamma) $\gamma$-one via an irreversible reconstruction mechanism (Delmas et al. 1994).

The lithium insertion/extraction of this active material in the $4-2.15 \mathrm{~V}$ potential range was analyzed through Raman micro-spectrometry, being detected the emergence of various $\mathrm{Li}_{\mathrm{x}} \mathrm{V}_{2} \mathrm{O}_{5}$ phases in the wide Li composition range $0<\mathrm{x}<2$ ( BaddourHadjean et al. 2012).

This electrode was prepared using the plasma enhanced chemical vapor deposition (PECVD) technique in which the optimized substrate temperature and radiofrequency (RF) power are $250^{\circ} \mathrm{C}$ and $50 \mathrm{~W}$, respectively (Liu et al. 1998).

The carbothermal reduction method was used for synthesizing this active material, that demonstrated a high reversible specific capacity of $130 \mathrm{mAh} . \mathrm{g}^{-1}$ (Barker et al. 2003).

Further, this active material was synthesized by the sol-gel method, it shows nanostructure and is capable of reversible cycling (Caes et al. 2014).

(gamma) $\gamma-\mathrm{LiV}_{2} \mathrm{O}_{5}$ was synthesized via a simple solvothermal method and exhibits a better electrochemical performance (Li et al. 2013b).

Three layered $\mathrm{Al}_{2} \mathrm{O}_{3} / \mathrm{Li}_{\mathrm{x}} \mathrm{V}_{2} \mathrm{O}_{5} / \mathrm{LiV}_{3} \mathrm{O}_{8}$ was prepared and the $\mathrm{Li}_{\mathrm{x}} \mathrm{V}_{2} \mathrm{O}_{5}$ middle layer contributes to the improvement of interfacial electrochemical properties of the hybrid electrode (Sun et al. 2015).

\subsubsection{2 $\quad \mathrm{LiV}_{3} \mathrm{O}_{8}$}

Lithium vanadium(V)oxide $\left(\mathrm{LiV}_{3} \mathrm{O}_{8}\right)$ is an active material very interesting for rechargeable batteries considering its high specific energy, long cycle and low cost (Wang et al. 2012). In addition to its properties and application as cathodic material, it has been also investigated for the anode, but with low capacity value (Köhler $e t$ al. 2000).

Its specific capacity of about $280 \mathrm{mAh} \cdot \mathrm{g}^{-1}$ has been achieved corresponding to the reversible intercalation of 3 equivalents of Li per mol Li ${ }_{1+x} \mathrm{~V}_{3} \mathrm{O}_{8}$ (Manev et al. 1995).

The atomic structures and the phase transition for $\mathrm{Li}_{1-\mathrm{x}} \mathrm{V}_{3} \mathrm{O}_{8}$ were calculated through the local-density-functional-theory as a function of lithiation and the structure of $1+\mathrm{x}$ $=1.2$ and $1+\mathrm{x}=4$ coincide with the predicted low-energy configurations (Benedek et al. 1999). Its lithium insertion kinetics was affected largely by the small diffusivity of $\mathrm{Li}^{+}$in the $\mathrm{Li}_{4} \mathrm{~V}_{3} \mathrm{O}_{8}$ phase formed for $\mathrm{x}>1.5$ upon lithiation (Kawakita et al. 1999).

The diffusion coefficient for this active material is relatively low $\left(\sim 10^{-12}-10^{-13} \mathrm{~cm}^{2}\right.$ $\left.\mathrm{s}^{-1}\right)$ and it is observed that it decreases with the intercalation of $\mathrm{Li}^{+}$, which slows down the mobility of the $\mathrm{Li}^{+}$ion (Bonino et al. 1995). During the first lithium electrochemical insertion-extraction process in the electrode surface it is observed the formation of $\mathrm{LiF}$ as well as compounds containing phosphorus originated by solid-electrolyte interface (SEI) formation (Choi et al. 2006; Chul Choi et al. 2003).

The effect of oxygen defects in the structure has been analyzed and it has been observed the formation of new sites available for the occupation of $\mathrm{Li}^{+}$ions (Kawakita et al. 1997b).

Their final properties of the active material depend on the conditions and methods of synthesis, which include sol-gel (citric acid, $\mathrm{C}_{6} \mathrm{H}_{8} \mathrm{O}_{7}$ and (hydrogen) peroxide, $\mathrm{H}_{2} \mathrm{O}_{2}$ ) 
(Feng et al. 2009a; and Wang et al. 2012), solution reaction (En-Hui et al. 2004), solidstate (Feng et al. 2009a), hydrothermal (Feng et al. 2009a) (Liu et al. 2007), aqueous precipitation (Feng et al. 2009a), mechanochemical (Kosova et al. 2001), microwave (Wu et al. 2009), soft-chemical via a low-temperature heating process (Feng et al. 2009b), spray pyrolysis (Ju and Kang 2011), and solid-state routine with quenching in freezing atmosphere (Liu et al. 2009b).

The influence of the synthesis method on its electrochemical performance was evaluated and it has been verified that the active material produced from the sol-gel citric acid method and the aqueous precipitation route presents excellent results (Feng et al. 2009a).

The polymer polyvinylpyrrolidone was used in the polymer precursor method for synthesizing this active material, leading to good cycling stability (Sakunthala et al. 2010). Another polymer such as polyethylene glycol ( $P E G, \mathrm{C}_{2 n} \mathrm{H}_{4 n}+2 \mathrm{O}_{n+1}$ ) was used in its synthesis (Sun et al. 2010).

The obtained morphologies are nanobelts (Fig. 10a) (Gu and Jian 2008), nanorods (Zhongxue et al. 2017), spheres (Ju and Kang 2011) (Fig. 10b), and flake like (Feng et al. 2009b).
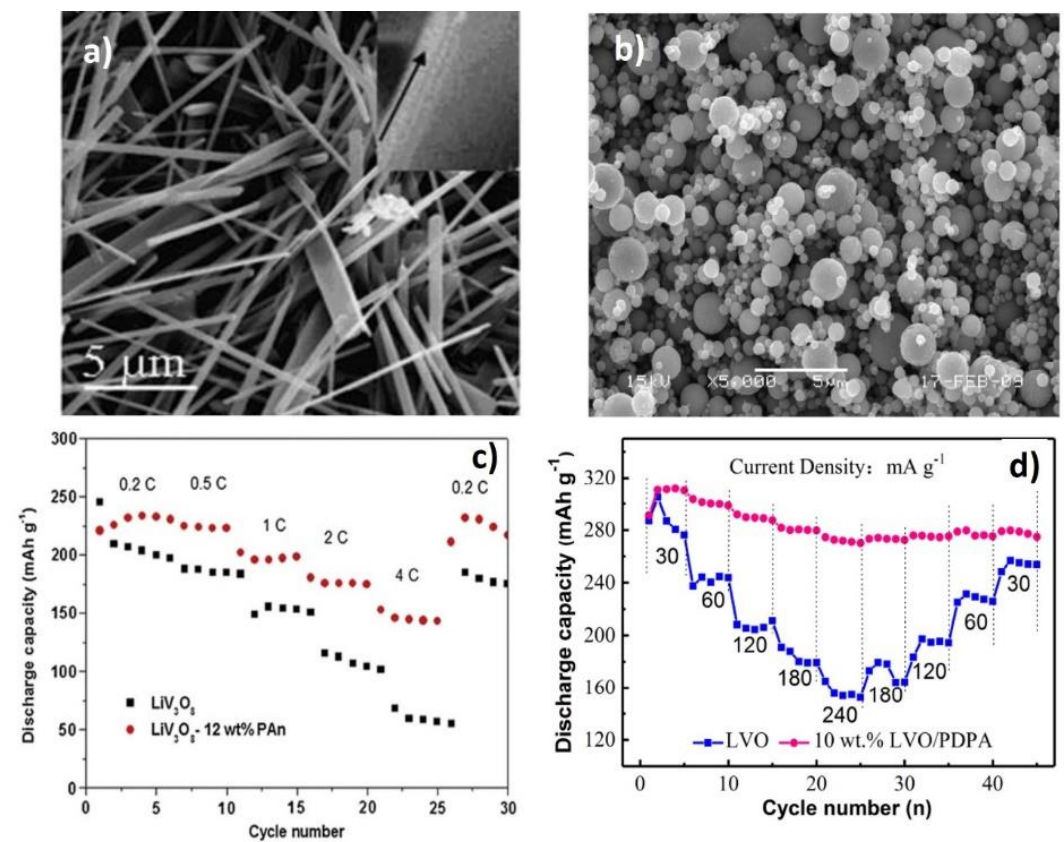

Fig. 10 a) SEM image of $\mathrm{Li}_{1+\mathrm{x}} \mathrm{V}_{3} \mathrm{O}_{8}$ nanobelts (Gu and Jian 2008) and b) spheres (Ju and Kang 2011). Cycling performance of $\mathrm{LiV}_{3} \mathrm{O}_{8}$ with c) polyaniline (Gao et al. 2012) and d) polydiphenylamine (Zhu et al. 2018b). 
It has been demonstrated that the nanorods morphology with high crystallinity greatly improves the stability of the crystallographic structure during cycling (Liu et al. 2009a).

For improving electrical conductivity and cycling performance, this compound was doped of with manganese (Kawakita et al. 1997a), molybdenum (Mo) (Song et al. 2015), chromium (Feng et al. 2009c), chlorine (Li et al. 2009) and titanium (Junli et al. 2009), and prepared in composites with polypyrrole [ polyaniline [ $\left.{ }^{A}\left[\mathrm{H}_{\mathrm{s}}\right\}_{\mathrm{n}}^{\mathrm{R}}\right]$ (Liang et al. 2014), polydiphenylamine [ 10d) (Zhu et al. 2018b), poly(1,5-diaminoanthraquinone) [ ${ }^{1}$ ]

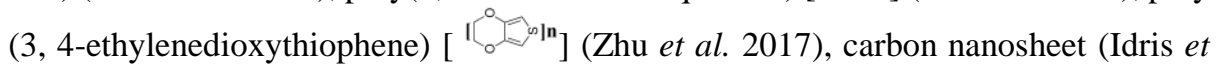
al. 2011), Silver (Ag) nanoparticles anchored in their nanobelts (Liang et al. 2014), polytriphenylamine [ 2016), multiwalled carbon nanotubes (MWCNT) (Zhong Ren et al. 2012), lithium manganese oxide $\left(\mathrm{LiMn}_{2} \mathrm{O}_{4}\right)$ (Zhao et al. 2011) and core-shell with lithium manganese cobalt nickel oxide $\left(\mathrm{Li}_{1.2} \mathrm{Mn}_{0.54} \mathrm{Co}_{0.13} \mathrm{Ni}_{0.13} \mathrm{O}_{2}\right)$ (Sun et al. 2016b).

\section{Conclusion}

In this chapter, the main promising cathode active materials were presented and their main properties analyzed. Different kinds of materials are used as a cathode material and some of them are already commercialized. A variety of active materials with a high range of specific capacities can be used on lithium-ion batteries for a different application. Different synthesis routes have been used to fabricate these materials including hydrothermal, sol-gel, precipitation, solid-state method, mechanochemical, microwave, soft-chemical via a low-temperature heating process, and spray pyrolysis, among others. For each synthesis procedure, it is possible to control one or more specific particle properties and therefore reaching a better and improved cathode material. It is also possible to state that nanosize and carbon coating has a crucial importance in the electrochemical performance. Another possible treatment is doping of the active material, allowing to overcome some intrinsic drawbacks of the pure active materials.

\section{Acknowledgments}

This work was supported by the Portuguese Foundation for Science and Technology (FCT) in the framework of the Strategic Funding UID/FIS/04650/2013 project PTDC/CTM-ENE/5387/2014, project $\mathrm{n}^{\circ} 28157 / 02 / \mathrm{SAICT} / 2017$ and grant SFRH/BPD/112547/2015 (C.M.C.). The authors thank the Basque Government Industry Department under the ELKARTEK and HAZITEK Programs for its financial support. 


\section{$4 \quad$ Author Contribution}

All authors performed the literature revision and critical review of the literature. Further, all authors contributed to the writing of the chapter. The authors further acknowledge that there is no financial relationship with the editors or publisher in this chapter, other than what acknowledged or appropriately cited with copyright permission.

\section{$5 \quad$ References}

Adipranoto DS et al. (2015) Crystal-Local Structure Analyses for Cathode LIBs $\mathrm{LiNi}_{1-x} \mathrm{Co}_{x} \mathrm{O}_{2}(0 \leq \mathrm{x} \leq 1)$ by Neutron Diffraction. In: Proceedings of the 2 nd International Symposium on Science at J-PARC? Unlocking the Mysteries of Life, Matter and the Universe ? vol 8. JPS Conference Proceedings, vol 8. Journal of the Physical Society of Japan. doi:doi:10.7566/JPSCP.8.031017

Anderson DN, Willett RD (1971) Refinement of the structure of $\mathrm{LiV}_{2} \mathrm{O}_{5}$ Acta Crystallographica Section B 27:1476-1477 doi:doi:10.1107/S0567740871004199

Andriyevsky B, Doll K, Jacob T (2014) Electronic and transport properties of $\mathrm{LiCoO}_{2}$ Physical Chemistry Chemical Physics 16:23412-23420 doi:10.1039/c4cp03052d

Aravindan V, Gnanaraj J, Lee Y-S, Madhavi S (2013) $\mathrm{LiMnPO}_{4}$ - A next-generation cathode material for lithium-ion batteries Journal of Materials Chemistry $A$ 1:3518-3539 doi:10.1039/C2TA01393B

Armstrong AR, Bruce PG (1996) Synthesis of layered $\mathrm{LiMnO}_{2}$ as an electrode for rechargeable lithium batteries Nature 381:499-500 doi:10.1038/381499a0

Asano T, Yubuchi S, Sakuda A, Hayashi A, Tatsumisago M (2017) Electronic and Ionic Conductivities of $\mathrm{LiNi1/3Mn1/3Co1/3O2-Li3PS4} \mathrm{Positive} \mathrm{Composite}$ Electrodes for All-Solid-State Lithium Batteries Journal of The Electrochemical Society 164: A3960-A3963 doi:10.1149/2.1501714jes

Auvergniot J, Cassel A, Ledeuil J-B, Viallet V, Seznec V, Dedryvère R (2017) Interface Stability of Argyrodite Li6PS5Cl toward $\mathrm{LiCoO}_{2}, \mathrm{LiNi}_{1 / 3} \mathrm{Co}_{1 / 3} \mathrm{Mn}_{1 / 3} \mathrm{O}_{2}$, and $\mathrm{LiMn}_{2} \mathrm{O}_{4}$ in Bulk All-Solid-State Batteries Chemistry of Materials 29:3883-3890 doi:10.1021/acs.chemmater.6b04990

Azib T, Le Cras F, Porthault H (2015) Direct fabrication of LiCoO2 thin-films in waterethanol solutions by electrochemical-hydrothermal method Electrochimica Acta 160:145-151 doi:10.1016/j.electacta.2015.01.091 
B. SS, J. B, M. J, P. GC, B. GJ (2006) $\mathrm{LiNi}_{1 / 2}+\delta \mathrm{Mn}_{1 / 2}-\delta \mathrm{O}_{2}-\mathrm{A}$ High - Rate, High Capacity Cathode for Lithium Rechargeable Batteries Advanced Materials 18:905-909 doi:doi:10.1002/adma.200500113

Baboo JP et al. (2017) Facile Redox Synthesis of Layered $\mathrm{LiNi}_{1 / 3} \mathrm{CO}_{1 / 3} \mathrm{Mn}_{1 / 3} \mathrm{O}_{2}$ for Rechargeable Li-ion Batteries Electrochimica Acta 224:243-250 doi:https://doi.org/10.1016/j.electacta.2016.12.050

Bai N, Chen H, Zhou W, Xiang K, Zhang Y, Li C, Lu H (2015) Preparation and electrochemical performance of LiFePO4/C microspheres by a facile and novel co-precipitation Electrochimica Acta $167: 172-178$ doi:10.1016/j.electacta.2015.03.163

Balakrishnan T, Sankarasubramanian N, Kavitha A, Kathalingam A (2018) Studies on structural, optical, electrical and morphological properties of $\mathrm{LiCoO}_{2}$ thin films prepared by sol-gel method Materials Research Innovations:1-6 doi:10.1080/14328917.2018.1431190

Bao L et al. (2015) Hydrothermal synthesis of flower-like $\mathrm{LiMnPO}_{4}$ nanostructures self-assembled with (010) nanosheets and their application in $\mathrm{Li}$-ion batteries CrystEngComm 17:6399-6405 doi:10.1039/C5CE01253H

Barker J, Saidi MY, Swoyer JL (2003) Performance Evaluation of the Electroactive Material, $\gamma-$ LiV2O5 , Made by a Carbothermal Reduction Method Journal of The Electrochemical Society 150: A1267-A1272 doi:10.1149/1.1600462

Benedek R, Thackeray MM, Yang LH (1999) First-principles calculation of atomic structure and electrochemical potential of $\mathrm{Li}_{1}+x \mathrm{~V}_{3} \mathrm{O}_{8}$ Journal of Power Sources 81-82:487-490 doi:https://doi.org/10.1016/S0378-7753(99)00208-6

Beninati S, Damen L, Mastragostino M (2009) Fast sol-gel synthesis of $\mathrm{LiFePO}_{4} / \mathrm{C}$ for high power lithium-ion batteries for hybrid electric vehicle application Journal of Power Sources 194:1094-1098 doi:https://doi.org/10.1016/j.jpowsour.2009.06.035

Bie $X$ et al. (2013) Spin glass transition in the rhombohedral $\mathrm{LiNi}_{1 / 3} \mathrm{CO}_{\frac{1}{3}} \mathrm{Mn}_{1 / 3} \mathrm{O}_{2}$ Journal of Alloys and Compounds 572:79-83 doi:https://doi.org/10.1016/j.jallcom.2013.03.242

Blomgren GE (2017) The Development and Future of Lithium-Ion Batteries Journal of The Electrochemical Society 164: A5019-A5025 doi:10.1149/2.0251701jes

Bonino F, Panero S, Pasquali M, Pistoia G (1995) Rechargeable lithium batteries based on $\mathrm{Li}_{1}+\mathrm{XV}_{3} \mathrm{O}_{8}$ thin films Journal of Power Sources 56:193-196 doi:https://doi.org/10.1016/0378-7753(95)80033-D 
Burukhin A, Brylev O, Hany P, Churagulov BR (2002) Hydrothermal synthesis of $\mathrm{LiCoO}_{2}$ for lithium rechargeable batteries Solid State lonics 151:259-263 doi:10.1016/S0167-2738(02)00721-X

Cabelguen P-E, Peralta D, Cugnet M, Maillet P (2017) Impact of morphological changes of $\mathrm{LiNi}_{1 / 3} \mathrm{CO}_{1 / 3} \mathrm{Mn}_{1 / 3} \mathrm{O}_{2}$ on lithium-ion cathode performances Journal of Power Sources 346:13-23 doi:https://doi.org/10.1016/j.jpowsour.2017.02.025

Caes S et al. (2014) Mesoporous lithium vanadium oxide as a thin film electrode for lithium-ion batteries: comparison between direct synthesis of $\mathrm{LiV}_{2} \mathrm{O}_{5}$ and electrochemical lithium intercalation in $\mathrm{V}_{2} \mathrm{O}_{5}$ Journal of Materials Chemistry $\mathrm{A}$ 2:5809-5815 doi:10.1039/C4TA00090K

Can Şener ŞE, Sharp JL, Anctil A (2018) Factors impacting diverging paths of renewable energy: A review Renewable and Sustainable Energy Reviews 81:23352342 doi:https://doi.org/10.1016/j.rser.2017.06.042

Cava RJ, Santoro A, Murphy DW, Zahurak SM, Fleming R, Marsh P, Roth RS (1986) The Structure of the Lithium-Inserted Metal Oxide $\mathrm{LiV}_{2} \mathrm{O}_{5}$ vol 65. doi:10.1016/0022-4596(86)90089-7

Ceder G, Mishra SK (1999) Stability of orthorhombic and monoclinic-layered $\mathrm{LiMnO}_{2}$ Electrochemical and Solid-State Letters 2:550-552 doi:10.1149/1.1390900

Chen B, Ben L, Yu H, Chen Y, Huang X (2018) Understanding Surface Structural Stabilization of the High-Temperature and High-Voltage Cycling Performance of $\mathrm{Al}^{3+}$-Modified $\mathrm{LiMn}_{2} \mathrm{O}_{4}$ Cathode Material ACS Applied Materials and Interfaces 10:550-559 doi:10.1021/acsami.7b14535

Chen Z, Xie T, Li L, Xu M, Zhu H, Wang W (2014a) Characterization of Na-substituted $\mathrm{LiNi}_{1 / 3} \mathrm{CO}_{\frac{1}{3}} \mathrm{Mn}_{\frac{1}{3}} \mathrm{O}_{2}$ cathode materials for lithium-ion battery lonics 20:629-634 doi:10.1007/s11581-013-1022-y

Chen Z, Xu M, Du B, Zhu H, Xie T, Wang W (2014b) Morphology control of lithium iron phosphate nanoparticles by soluble starch-assisted hydrothermal synthesis Journal of Power Sources 272:837-844 doi:https://doi.org/10.1016/j.jpowsour.2014.09.019

Cherkouk C, Nestler T Cathodes - a Technological review. In: AIP Conference Proceedings, 2014. pp 134-145. doi:10.1063/1.4878484

Cho E, Seo S-W, Min K (2017) Theoretical Prediction of Surface Stability and Morphology of $\mathrm{LiNiO}_{2}$ Cathode for Li-Ion Batteries ACS Applied Materials \& Interfaces 9:33257-33266 doi:10.1021/acsami.7b08563 
Cho J, Kim TJ, Park B (2002) The effect of a metal-oxide coating on the cycling behavior at $55^{\circ} \mathrm{C}$ in orthorhombic $\mathrm{LiMnO}_{2}$ cathode materials Journal of the Electrochemical Society 149: A288-A292 doi:10.1149/1.1446870

Cho J, Yong Jeong K, Kim TJ, Park B (2001) Enhanced structural stability of o- LiMnO by a sol-gel coating of $\mathrm{Al}_{2} \mathrm{O}_{3}$ Chemistry of Materials 13:18-20 doi:10.1021/cm000759+

Choi D, Li X, Henderson WA, Huang Q, Nune SK, Lemmon JP, Sprenkle VL (2016) $\mathrm{LiCoPO}_{4}$ cathode from a $\mathrm{CoHPO}_{4} \cdot \mathrm{xH}_{2} \mathrm{O}$ nanoplate precursor for high voltage $\mathrm{Li}$ ion batteries Heliyon 2 doi:10.1016/j.heliyon.2016.e00081

Choi HC, Kim SB, Jung YM (2006) Application of soft X-ray absorption spectroscopy and two-dimensional correlation spectroscopy to the electrochemical reaction in the $\mathrm{Li}_{1}+x \mathrm{~V}_{3} \mathrm{O}_{8} / \mathrm{Li}$ cell Journal of Molecular Structure 799:91-95 doi:https://doi.org/10.1016/j.molstruc.2006.03.022

Christiansen TL, Bojesen ED, Sondergaard M, Birgisson S, Becker J, Iversen BB (2016) Crystal structure, microstructure and electrochemical properties of hydrothermally synthesized $\quad \mathrm{LiMn}_{2} \mathrm{O}_{4} \quad$ CrystEngComm 18:1996-2004 doi:10.1039/c5ce02358k

Chul Choi H, Kyu Lee M, Joon Shin H, Bin Kim S (2003) Investigation of the $\mathrm{Li}_{1}+x \mathrm{~V}_{3} \mathrm{O}_{8}$ electrode-organic electrolyte interface by scanning photoelectron microscopy Journal of Electron Spectroscopy and Related Phenomena 130:85-96 doi:https://doi.org/10.1016/S0368-2048(03)00087-2

Cong $\mathrm{L}$ et al. (2016) $\left(\mathrm{PO}_{4}\right)_{3}{ }^{-}$polyanions doped $\mathrm{LiNi}_{\frac{1}{3}} \mathrm{CO}_{\frac{1}{3}} \mathrm{Mn}_{\frac{1}{3} \mathrm{O}_{2}}$ : An ultrafast-rate, long-life and high-voltage cathode material for $\mathrm{Li}$-ion rechargeable batteries Electrochimica Acta doi:https://doi.org/10.1016/j.electacta.2016.03.088

Crompton KR, Hladky MP, Staub JW, Landi BJ (2017) Enhanced overdischarge stability of $\mathrm{LiCoO}_{2}$ by a solution deposited AIPO4 coating Journal of the Electrochemical Society 164: A3214-A3219 doi:10.1149/2.1171713jes

Cui Y, Yang C, Zhuang Z, Wang M, Zhuang Q (2018) Synthesis and Electrochemical Performance of Spheroid $\mathrm{LiNi}_{1 / 3} \mathrm{CO}_{1 / 3} \mathrm{Mn}_{\frac{1}{3}} \mathrm{O}_{2}$ in the Electrolyte Modified by Ethylene Sulfate and Methylene Methanedisulfonate Journal of Inorganic and Organometallic Polymers and Materials 28:731-737 doi:10.1007/s10904-0170722-6

Dang $\mathrm{R}$ et al. (2017) Lithium-ion Conductor and Electronic Conductor Co-coating Modified Layered Cathode Material $\mathrm{LiNi}_{1 / 3} \mathrm{CO}_{\frac{1}{3}} \mathrm{Mn}_{1 / 3} \mathrm{O}_{2}$ Electrochimica Acta 247:443450 doi:https://doi.org/10.1016/j.electacta.2017.07.041 
Daniel C, Mohanty D, Li J, Wood DL Cathode materials review. In: AIP Conference Proceedings, 2014. pp 26-43. doi:10.1063/1.4878478

Davidson IJ, McMillan RS, Murray JJ, Greedan JE (1995) Lithium-ion cell based on orthorhombic $\mathrm{LiMnO}_{2}$ Journal of Power Sources 54:232-235 doi:10.1016/03787753(94)02074-D

Deb A, Bergmann U, Cramer SP, Cairns EJ (2006) Local structure of LiNi $\mathrm{Ni}_{1 / 2} \mathrm{Mn}_{\frac{1}{2}} \mathrm{O}_{2}$ cathode material probed by insitu x-ray absorption spectroscopy Journal of Applied Physics 99:063701 doi:10.1063/1.2179198

Delacourt C, Wurm C, Reale P, Morcrette M, Masquelier C (2004) Low-temperature preparation of optimized phosphates for Li-battery applications Solid State Ionics 173:113-118 doi:https://doi.org/10.1016/j.ssi.2004.07.061

Delmas C, Brèthes S, Ménétrier M (1991) $\omega$ - $\mathrm{Li}_{x} \mathrm{~V}_{2} \mathrm{O}_{5}$ - a new electrode material for rechargeable lithium batteries Journal of Power Sources 34:113-118 doi:https://doi.org/10.1016/0378-7753(91)85030-Z

Delmas C, Cognac-Auradou H, Cocciantelli JM, Ménétrier M, Doumerc JP (1994) The $\mathrm{LixV}_{2} \mathrm{O}_{5}$ system: An overview of the structural modifications induced by the lithium intercalation Solid State Ionics 69:257-264 doi:https://doi.org/10.1016/01672738(94)90414-6

Delmas C, Saadoune I (1992) Electrochemical and physical properties of the $\mathrm{Li}_{x} \mathrm{Ni}_{1-y} \mathrm{Co}_{y} \mathrm{O}_{2}$ phases Solid State Ionics 53-56:370-375 doi:https://doi.org/10.1016/0167-2738(92)90402-B

Deng X-r, Hu G-r, Du K, Peng Z-d, Gao X-G, Yang Y-N (2008) Synthesis and electrochemical properties of $\mathrm{Co}, \mathrm{Mn}$-coated $\mathrm{LiNiO}_{2}$ lithium-ion battery cathode materials Materials Chemistry and Physics 109:469-474 doi:https://doi.org/10.1016/j.matchemphys.2007.12.025

Diouf B, Pode R (2015) Potential of lithium-ion batteries in renewable energy Renewable Energy 76:375-380 doi:https://doi.org/10.1016/j.renene.2014.11.058

Dou J, Kang X, Wumaier T, Yu H, Hua N, Han Y, Xu G (2012) Effect of a lithium boron oxide glass coating on the electrochemical performance of $\mathrm{LiNi}_{1 / 3} \mathrm{CO}_{\frac{1}{3}} \mathrm{Mn}_{1 / 3} \mathrm{O}_{2}$ Journal of Solid State Electrochemistry 16:1481-1486 doi:10.1007/s10008-0111550-1

Dou S, Li Q (2014) Synthesis and Electrochemical Properties of Hexagonal Sliced $\mathrm{LiNi} \frac{1}{2} \mathrm{Mn}_{1 / 2} \mathrm{O}_{2}$ as Cathode Materials for Li-ion Batteries vol 26. doi:10.14233/ajchem.2014.15771 
Dupré N, Martin J-F, Guyomard D, Yamada A, Kanno R (2009) Characterization of interphases appearing on $\mathrm{LiNi}_{1 / 2} \mathrm{Mn}_{\frac{1}{2}} \mathrm{O}_{2}$ using $7 \mathrm{Li} \mathrm{MAS} \mathrm{NMR} \mathrm{Journal} \mathrm{of} \mathrm{Power}$ Sources 189:557-560 doi:https://doi.org/10.1016/j.jpowsour.2008.10.017

En-Hui L, Xin-Hai L, Zhao-Hui H, Ze-Qiang H, Ling-Feng D (2004) Chemical Diffusion Behaviors of Lithium-ion in the LiV308 Prepared by Wet Method Reaction Acta Phys -Chim Sin 20:377-381 doi:10.3866/pku.whxb20040409

Fan J (2004) Studies of 18650 cylindrical cells made with doped $\mathrm{LiNiO}_{2}$ positive electrodes for military applications Journal of Power Sources 138:288-293 doi:https://doi.org/10.1016/j.jpowsour.2004.06.010

Feng CQ, Chew SY, Guo ZP, Wang JZ, Liu HK (2007) An investigation of polypyrrole$\mathrm{LiV}_{3} \mathrm{O}_{8}$ composite cathode materials for lithium-ion batteries Journal of Power Sources 174:1095-1099 doi:https://doi.org/10.1016/j.jpowsour.2007.06.190

Feng J, Liu X, Zhang X, Jiang J, Zhao J, Wang M (2009a) Effects of Synthesis Methods on $\mathrm{Li}_{1}+x \mathrm{~V}_{3} \mathrm{O}_{8}$ as Cathodes in Lithium-Ion Batteries Journal of The Electrochemical Society 156:A768-A771 doi:10.1149/1.3174386

Feng Y, Hou F, Li Y (2009b) A new low-temperature synthesis and electrochemical properties of $\mathrm{LiV}_{3} \mathrm{O}_{8}$ hydrate as cathode material for lithium-ion batteries Journal of Power Sources 192:708-713 doi:https://doi.org/10.1016/j.jpowsour.2009.02.079

Feng Y, Li Y, Hou F (2009c) Preparation and electrochemical properties of Cr doped $\mathrm{LiV}_{3} \mathrm{O}_{8}$ cathode for lithium-ion batteries Materials Letters 63:1338-1340 doi:https://doi.org/10.1016/j.matlet.2009.03.009

Fonseca CP, Paula RM, Pallone EMJA, Neves S (2006) A new approach to obtain lithium nickel cobalt oxide porous films Electrochimica Acta 51:6419-6425 doi:https://doi.org/10.1016/j.electacta.2006.04.026

Fransson L, Eriksson T, Edström K, Gustafsson T, Thomas JO (2001) Influence of carbon black and binder on Li-ion batteries Journal of Power Sources 101:1-9 doi:https://doi.org/10.1016/S0378-7753(01)00481-5

Fujii Y, Miura H, Suzuki N, Shoji T, Nakayama N (2007) Structural and electrochemical properties of LiNi1/3Co1/3Mn1/302: Calcination temperature dependence Journal of Power Sources 171:894-903 doi:https://doi.org/10.1016/j.jpowsour.2007.06.017

Fujimoto D, Lei Y, Huang Z-H, Kang F, Kawamura J (2014) Synthesis and Electrochemical Performance of LiMnPO4 by Hydrothermal Method International Journal of Electrochemistry 2014:9 doi:10.1155/2014/768912 
Gao S et al. (2015) Sol-gel synthesis and electrochemical properties of c-axis oriented $\mathrm{LiCoO}_{2}$ for lithium-ion batteries RSC Advances 5:51483-51488 doi:10.1039/c5ra06571b

Gao X-W, Wang J-Z, Chou S-L, Liu H-K (2012) Synthesis and electrochemical performance of $\mathrm{LiV}_{3} \mathrm{O}_{8} /$ polyaniline as cathode material for the lithium battery Journal of Power 220:47-53 doi:https://doi.org/10.1016/j.jpowsour.2012.07.114

Geaney H, O'Dwyer C (2016) Examining the Role of Electrolyte and Binders in Determining Discharge Product Morphology and Cycling Performance of Carbon Cathodes in Li- $\mathrm{O}_{2}$ Batteries Journal of The Electrochemical Society 163:A43-A49 doi:10.1149/2.1011514jes

Gong C et al. (2014) Syntheses and electrochemical properties of layered

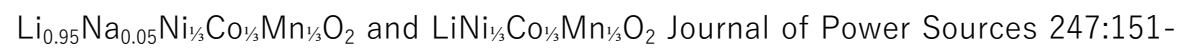
155 doi:https://doi.org/10.1016/j.jpowsour.2013.08.081

Goodenough JB, Park K-S (2013) The Li-Ion Rechargeable Battery: A Perspective Journal of the American Chemical Society 135:1167-1176 doi:10.1021/ja3091438

Gören A, Costa CM, Silva MM, Lanceros-Méndez S (2015) State of the art and open questions on cathode preparation based on carbon-coated lithium iron phosphate Composites Part B: 8ngineering 83:333-345 doi:https://doi.org/10.1016/j.compositesb.2015.08.064

Gu H-B, Jin B, Jun D-K, Han Z (2007) Improved Electrochemical Performance of $\mathrm{LiCoPO}_{4}$ Nanoparticles for Lithium-Ion Batteries vol 7. doi:10.1166/jnn.2007.078

Gu Y, Jian F (2008) Facile preparation and electrochemical properties of large-scale $\mathrm{Li}_{1}+x \mathrm{~V}_{3} \mathrm{O}_{8}$ nanobelts Journal of Sol-Gel Science and Technology 46:161-165 doi:10.1007/s10971-008-1711-6

Guan J et al. (2017) Mechanochemical Process Enhanced Cobalt and Lithium Recycling from Wasted Lithium-Ion Batteries ACS Sustainable Chemistry \& Engineering 5:1026-1032 doi:10.1021/acssuschemeng.6b02337

Guo X, Greenbaum S, Ronci F, Scrosati B (2004) X-ray diffraction and 7Li nuclear magnetic resonance studies of iron- and cobalt-substituted $\mathrm{LiNiO}_{2}$ prepared from inorganic transition metal nitrates Solid State lonics 168:37-49 doi:https://doi.org/10.1016/j.ssi.2004.02.006

Habte BT, Jiang F (2018) Microstructure reconstruction and impedance spectroscopy study of LiCoO2, LiMn2O4 and LiFePO4 Li-ion battery cathodes Microporous and Mesoporous Materials 268:69-76 doi:10.1016/j.micromeso.2018.04.001 
Han L, Yu C, Wang Q, Guo S, Xu K, Zhang W, Yang R (2018) Mechanism of the Enhanced Electrochemical Properties of $\mathrm{LiNi}_{1 / 3} \mathrm{Co}_{\frac{1}{3}} \mathrm{Mn}_{1 / 3} \mathrm{O}_{2}$ Cathode Materials by a Pre-Sintering Process Russian Journal of Electrochemistry 54:49-55 doi:10.1134/s1023193518010044

Han X, Meng Q, Sun T, Sun J (2010) Preparation and electrochemical characterization of single-crystalline spherical LiNi1/3Co1/3Mn1/302 powders cathode material for Li-ion batteries Journal of Power Sources 195:3047-3052 doi:https://doi.org/10.1016/j.jpowsour.2009.11.007

Han Y-m, Zhang Z-f, Zhang L-b, Peng J-h, Fu M-b, Srinivasakannan C, Du J (2013) Influence of carbon coating prepared by microwave pyrolysis on properties of $\mathrm{LiNi} 1 / 3 \mathrm{CO}_{1 / 3} \mathrm{Mn}_{1 / 3} \mathrm{O}_{2}$ Transactions of Nonferrous Metals Society of China 23:29712976 doi:https://doi.org/10.1016/S1003-6326(13)62822-8

Hashem AM, Abdel-Ghany AE, Abuzeid HM, Ehrenberg H, Mauger A, Groult H, Julien CM (2013) LiNi1/3Mn1/3Co1/302 Synthesized by Sol-Gel Method: Structure and Electrochemical Properties ECS Transactions 50:91-96 doi:10.1149/05024.0091ecst

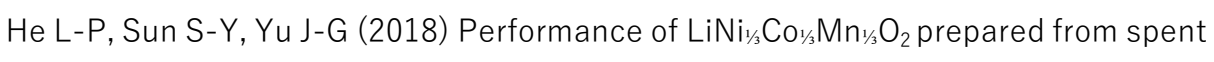
lithium-ion batteries by a carbonate co-precipitation method Ceramics International 44:351-357 doi:https://doi.org/10.1016/j.ceramint.2017.09.180

He R, Zhang L, Yan M, Gao Y, Liu Z (2017) Effects of $\mathrm{Cr}_{2} \mathrm{O}_{3}$-modified LiNi $\mathrm{Li}_{\frac{1}{3}} \mathrm{Co}_{1 / 3} \mathrm{Mn}_{1 / 3} \mathrm{O}_{2}$ cathode materials on the electrochemical performance of lithium-ion batteries Journal of Materials Science 52:4599-4607 doi:10.1007/s10853-016-0704-z

Herle PS, Ellis B, Coombs N, Nazar LF (2004) Nano-network electronic conduction in iron and nickel olivine phosphates Nature Materials 3:147-152 doi:10.1038/nmat1063

Hou Q, Cao G, Wang P, Zhao D, Cui X, Li S, Li C (2018a) Carbon coating nanostructured-LiNi1/3Co1/3Mn1/302 cathode material synthesized by chemical vapor deposition method for high performance lithium-ion batteries Journal of Alloys and Compounds 747:796-802 doi:https://doi.org/10.1016/j.jallcom.2018.03.115

Hou Y et al. (2018b) Highly [010]-oriented self-assembled $\mathrm{LiCoPO}_{4} / \mathrm{C}$ nanoflakes as high-performance cathode for lithium-ion batteries Nano Research 11:2424-2435 doi:10.1007/s12274-017-1864-0

Hu C, Guo J, Wen J, Peng Y, Chen Y (2013) Preparation and electrochemical performance of $\mathrm{LiNi}_{1 / 2} \mathrm{Mn}_{1 / 2} \mathrm{O}_{2}-x \mathrm{~F}_{\mathrm{x}}(0 \leqslant x \leqslant 0.04)$ cathode material synthesized with 
hydroxide co-precipitation for lithium-ion batteries Journal of Alloys and Compounds 581:121-127 doi:https://doi.org/10.1016/j.jallcom.2013.05.223

Hu GR, Liao G, Peng ZD, Xiao J, Zhang XL, Yu XY (2004) Structure and electrochemical properties of $\mathrm{LiCoO}_{2}$ synthesized by microwave heating Journal of Central South University of Technology (English Edition) 11:261-264 doi:10.1007/s11771-004-0053-y

Hu S-K, Cheng G-H, Cheng M-Y, Hwang B-J, Santhanam R (2009) Cycle life improvement of $\mathrm{ZrO}_{2}$-coated spherical $\mathrm{LiNi}_{1 / 3} \mathrm{Co}_{1 / 3} \mathrm{Mn}_{1 / 3} \mathrm{O}_{2}$ cathode material for lithium ion batteries Journal of Power Sources 188:564-569 doi:https://doi.org/10.1016/j.jpowsour.2008.11.113

Huang B, Jang Y-I, Chiang Y-M, Sadoway DR (1998) Electrochemical evaluation of $\mathrm{LiCoO}_{2}$ synthesized by decomposition and intercalation of hydroxides for lithiumion battery applications Journal of Applied Electrochemistry 28:1365-1369 doi:10.1023/a:1003443108681

Idris NH, Rahman MM, Wang J-Z, Chen Z-X, Liu H-K (2011) Synthesis and electrochemical performance of $\mathrm{LiV}_{3} \mathrm{O}_{8} /$ carbon nanosheet composite as cathode material for lithium-ion batteries Composites Science and Technology 71:343-349 doi:https://doi.org/10.1016/j.compscitech.2010.11.025

Inagaki M, Konno H, Tanaike O (2010) Carbon materials for electrochemical capacitors Journal of Power Sources 195:7880-7903 doi:https://doi.org/10.1016/j.jpowsour.2010.06.036

Jacas BJ, Cristina F, Laura S, Ramon MJ (2016) Static and Dynamic Studies on $\mathrm{LiNi}_{1 / 3} \mathrm{CO}_{1 / 3} \mathrm{Mn}_{1 / 3} \mathrm{O}_{2}$ - Based Suspensions for Semi-Solid Flow Batteries ChemSusChem 9:1938-1944 doi:doi:10.1002/cssc.201600285

Jang YI, Huang B, Wang H, Sadoway DR, Chiang YM (1999) Electrochemical Cycling - Induced Spinel Formation in High - Charge - Capacity Orthorhombic $\mathrm{LiMnO}_{2}$ Journal of The Electrochemical Society 146:3217-3223 doi:10.1149/1.1392457

Jeong $\mathrm{KH}$, Ha H-W, Yun NJ, Hong $\mathrm{MZ}$, Kim K (2005) Zr-doped $\mathrm{Li}\left[\mathrm{Ni}_{1 / 2}-x \mathrm{Mn}_{1 / 2}-x Z \mathrm{r}_{2 x}\right] \mathrm{O}_{2}(\mathrm{x}=0,0.025)$ as cathode material for lithium ion batteries Electrochimica Acta 50:5349-5353 doi:https://doi.org/10.1016/j.electacta.2005.03.014

Jiang Q, Lang P, Li J, Tang J (2018) Improving the elevated-temperature behaviors of $\mathrm{LiNi}_{1 / 3} \mathrm{Co}_{1 / 3} \mathrm{Mn}_{1 / 3} \mathrm{O}_{2}$ by surface modification with Nano- $\mathrm{La}_{2} \mathrm{O}_{3}$ Journal of Alloys and Compounds 742:549-554 doi:https://doi.org/10.1016/j.jallcom.2018.01.354 
Jiang Q, Liu D, Zhang H, Wang S (2015) Plasma-Assisted Sulfur Doping of $\mathrm{LiMn}_{2} \mathrm{O}_{4}$ for High-Performance Lithium-Ion Batteries Journal of Physical Chemistry C 119:28776-28782 doi:10.1021/acs.jpcc.5b10298

Jin EM, Jin B, Jeon YS, Park KH, Gu HB (2009) Electrochemical properties of $\mathrm{LiMnO}_{2}$ for lithium polymer battery Journal of Power Sources 189:620-623 doi:10.1016/j.jpowsour.2008.09.102

Ju SH, Kang YC (2011) Effect of preparation temperature on the morphology, crystal structure and electrochemical properties of $\mathrm{LiV}_{3} \mathrm{O}_{8}$ powders prepared by spray pyrolysis Materials Chemistry and Physics 126:133-137 doi:https://doi.org/10.1016/j.matchemphys.2010.11.050

Julien C, Mauger A, Vijh A, Zaghib K (2015) Lithium Batteries: Science and Technology. Springer International Publishing,

Julien C, Mauger A, Zaghib K, Groult H (2016) Optimization of Layered Cathode Materials for Lithium-Ion Batteries Materials 9:595

Junli S et al. (2009) Synthesis and Electrochemical Performance of $\mathrm{Ti}^{4+}$ Doped $\mathrm{LiV}_{3} \mathrm{O}_{8}$ Chinese Journal of Chemistry 27:863-867 doi:doi:10.1002/cjoc.200990145

Kageyama M, Li D, Kobayakawa K, Sato Y, Lee Y-S (2006) Structural and electrochemical properties of $\mathrm{LiNi}_{1 / 3} \mathrm{CO}_{\frac{1}{3}} \mathrm{Mn}_{1 / 3} \mathrm{O}_{2}-x \mathrm{~F}_{x}$ prepared by solid-state reaction Journal of Power Sources 157:494-500 doi:https://doi.org/10.1016/j.jpowsour.2005.08.002

Kang H-K, Jung B-Y, Kim M-G, Lee Y, Kim D-M, Ryu K, Han K-S (2004) Direct thermal reaction for preparation of lithiated cathode materials without any artificial mixing procedures Solid State lonics 169:151-159 doi:https://doi.org/10.1016/j.ssi.2003.08.059

Kang K, Meng YS, Bréger J, Grey CP, Ceder G (2006) Electrodes with High Power and High Capacity for Rechargeable Lithium Batteries Science 311:977-980 doi:10.1126/science.1122152

Karino W (2016) Order of the transition metal layer in $\mathrm{LiNi}_{1 / 3} \mathrm{Co}_{1 / 3} \mathrm{Mn}_{1 / 3} \mathrm{O}_{2}$ and stability of the crystal structure lonics 22:991-995 doi:10.1007/s11581-016-1706-1

Karthik Prabhu S, Hirankumar G, Maheswaran A, Daries Bella RS, Sanjeeviraja C (2014) Structural and electrical studies on $\mathrm{Zn}^{2+}$ doped $\mathrm{LiCoPO}_{4}$ Journal of Electrostatics 72:181-186 doi:10.1016/j.elstat.2014.02.001

Kasnatscheew J, Evertz M, Streipert B, Wagner R, Nowak S, Cekic Laskovic I, Winter M (2017) Changing Established Belief on Capacity Fade Mechanisms: Thorough Investigation of $\mathrm{LiNi}_{1 / 3} \mathrm{Co}_{1 / 3} \mathrm{Mn}_{1 / 3} \mathrm{O}_{2}$ (NCM111) under High Voltage Conditions The Journal of Physical Chemistry C 121:1521-1529 doi:10.1021/acs.jpcc.6b11746 
Kasnatscheew J et al. (2016) Learning from Overpotentials in Lithium-Ion Batteries: A Case Study on the $\mathrm{LiNi}_{1 / 3} \mathrm{CO}_{1 / 3} \mathrm{Mn}_{1 / 3} \mathrm{O}_{2}$ (NCM) Cathode Journal of The Electrochemical Society 163:A2943-A2950 doi:10.1149/2.0461614jes

Kawakita J, Katagiri H, Miura T, Kishi T (1997a) Lithium insertion behaviour of manganese or molybdenum substituted $\mathrm{Li}_{1}+x \mathrm{~V}_{3} \mathrm{O}_{8}$ Journal of Power Sources 68:680-685 doi:https://doi.org/10.1016/S0378-7753(96)02596-7

Kawakita J, Majima M, Miura T, Kishi T (1997b) Preparation and lithium insertion behaviour of oxygen-deficient $\mathrm{Li}_{1}+x \mathrm{~V}_{3} \mathrm{O}_{8}-\delta$ Journal of Power Sources 66:135139 doi:https://doi.org/10.1016/S0378-7753(96)02540-2

Kawakita J, Miura T, Kishi T (1999) Lithium insertion and extraction kinetics of $\mathrm{Li}_{1}+x \mathrm{~V}_{3} \mathrm{O}_{8}$ Journal of Power Sources 83:79-83 doi:https://doi.org/10.1016/S03787753(99)00270-0

Kim B-H, Kim J-H, Kwon I-H, Song M-Y (2007) Electrochemical properties of $\mathrm{LiNiO}_{2}$ cathode material synthesized by the emulsion method Ceramics International 33:837-841 doi:https://doi.org/10.1016/j.ceramint.2006.01.021

Kim Y, Kim HS, Martin SW (2006) Synthesis and electrochemical characteristics of $\mathrm{Al}_{2} \mathrm{O}_{3}$-coated $\mathrm{LiNi}_{1 / 3} \mathrm{CO}_{1 / 3} \mathrm{Mn}_{1 / 3} \mathrm{O}_{2}$ cathode materials for lithium-ion batteries Electrochimica Acta 52:1316-1322 doi:https://doi.org/10.1016/j.electacta.2006.07.033

Kinoshita A, Yanagida K, Yanai A, Kida Y, Funahashi A, Nohma T, Yonezu I (2001) Electrochemical characteristics of $\mathrm{LiNi}_{1-x} \mathrm{Co}_{x} \mathrm{O}_{2}$ as positive electrode materials for lithium secondary batteries Journal of Power Sources 102:283-287 doi:https://doi.org/10.1016/S0378-7753(01)00806-0

Köhler J, Makihara H, Uegaito $\mathrm{H}$, Inoue H, Toki M (2000) $\mathrm{LiV}_{3} \mathrm{O}_{8}$ : characterization as anode material for an aqueous rechargeable $\mathrm{Li}$-ion battery system Electrochimica Acta 46:59-65 doi:https://doi.org/10.1016/S0013-4686(00)00515-6

Kong F, Liang C, Longo RC, Zheng Y, Cho K (2018) Atomic-scale understanding of non-stoichiometry effects on the electrochemical performance of $\mathrm{Ni}$-rich cathode materials Journal of Power Sources 378:750-758 doi:https://doi.org/10.1016/j.jpowsour.2018.01.008

Kosova NV, Vosel SV, Anufrienko VF, Vasenin NT, Devyatkina ET (2001) Reduction Processes in the Course of Mechanochemical Synthesis of $\mathrm{Li}_{1}+x \mathrm{~V}_{3} \mathrm{O}_{8}$ Journal of Solid State Chemistry 160:444-449 doi:https://doi.org/10.1006/jssc.2001.9272

Kreder KJ, Assat G, Manthiram A (2016) Aliovalent Substitution of $\mathrm{V}^{3+}$ for $\mathrm{Co}^{2+}$ in $\mathrm{LiCoPO}_{4}$ by a Low-Temperature Microwave-Assisted Solvothermal Process Chemistry of Materials 28:1847-1853 doi:10.1021/acs.chemmater.5b05042 
Lee YS, Yoshio M (2001) Preparation of orthorhombic $\mathrm{LiMnO}_{2}$ material by quenching Electrochemical and Solid-State Letters 4:A166-A169 doi:10.1149/1.1399879

Leger C, Bach S, Soudan P, Pereira-Ramos J-P (2005) Structural and Electrochemical Properties of $\omega$-Li $x \mathrm{~V}_{2} \mathrm{O}_{5} \quad(0.4 \leqslant x \leqslant 3)$ as Rechargeable Cathodic Material for Lithium Batteries Journal of The Electrochemical Society 152:A236-A241 doi:10.1149/1.1836155

Li D, Kato Y, Kobayakawa K, Noguchi H, Sato Y (2006a) Preparation and electrochemical characteristics of $\mathrm{LiNi}_{1 / 3} \mathrm{CO}_{\frac{1}{3}} \mathrm{Mn}_{\frac{1}{3}} \mathrm{O}_{2}$ coated with metal oxides coating Journal of Power Sources 160:1342-1348 doi:https://doi.org/10.1016/j.jpowsour.2006.02.080

Li D, Peng Z, Ren H, Guo W, Zhou Y (2008) Synthesis and characterization of $\mathrm{LiNi}_{1-x} \mathrm{Co}_{x} \mathrm{O}_{2}$ for lithium batteries by a novel method Materials Chemistry and Physics 107:171-176 doi:https://doi.org/10.1016/j.matchemphys.2007.06.069

Li D, Sasaki Y, Kobayakawa K, Noguchi H, Sato Y (2006b) Preparation, morphology and electrochemical characteristics of $\mathrm{LiNi}_{1 / 3} \mathrm{CO}_{1 / 3} \mathrm{Mn}_{\frac{1}{3}} \mathrm{O}_{2}$ with $\mathrm{LiF}$ addition Electrochimica Acta 52:643-648 doi:https://doi.org/10.1016/j.electacta.2006.05.044

Li J, Cao C, Xu X, Zhu Y, Yao R (2013a) LiNi $\mathrm{i}_{3 / 3} \mathrm{Co}_{\frac{1}{3}} \mathrm{Mn}_{1 / 3} \mathrm{O}_{2}$ hollow nano-micro hierarchical microspheres with enhanced performances as cathodes for lithiumion batteries Journal of Materials Chemistry A 1:11848-11852 doi:10.1039/C3TA12375H

Li J, Li M, Zhang L, Wang J (2016) General synthesis of $x \mathrm{Li}_{2} \mathrm{MnO}_{3}$ [middle dot] (1-x) $\mathrm{LiNi}_{1 / 3} \mathrm{CO}_{1 / 3} \mathrm{Mn}_{1 / 3} \mathrm{O}_{2}(x=1 / 4,1 / 3$, and $1 / 2)$ hollow microspheres towards enhancing the performance of rechargeable lithium-ion batteries Journal of Materials Chemistry A 4:12442-12450 doi:10.1039/C6TA04219H

Li J, Luo S, Ding X, Wang Q, He P (2018a) Three-Dimensional Honeycomb-Structural $\mathrm{LiAlO}_{2}$ Modified $\mathrm{LiMnPO}_{4}$ Composite with Superior High Rate Capability as Li-Ion Battery Cathodes ACS Applied Materials \& Interfaces 10:10786-10795 doi:10.1021/acsami.7b17597

Li J, Yao R, Cao C (2014) $\mathrm{LiNi}_{1 / 3} \mathrm{CO}_{\frac{1}{3}} \mathrm{Mn}_{\frac{1}{3}} \mathrm{O}_{2}$ Nanoplates with \{010\} Active Planes Exposing Prepared in Polyol Medium as a High-Performance Cathode for Li-Ion Battery ACS Applied Materials \& Interfaces 6:5075-5082 doi:10.1021/am500215b

Li L, Bian Y, Zhang X, Xue Q, Fan E, Wu F, Chen R (2018b) Economical recycling process for spent lithium-ion batteries and macro- and micro-scale mechanistic study Journal of Power Sources 377:70-79 doi:https://doi.org/10.1016/j.jpowsour.2017.12.006 
Li L, Cao Y, Zheng H, Feng C (2017a) $\mathrm{AlPO}_{4}$ coated $\mathrm{LiNi}_{1 / 3} \mathrm{Co}_{1 / 3} \mathrm{Mn}_{1 / 3} \mathrm{O}_{2}$ for high performance cathode material in lithium batteries Journal of Materials Science: Materials in Electronics 28:1925-1930 doi:10.1007/s10854-016-5745-1

Li L, Lifang J, Junli S, Sichen L, Huatang Y, Yongmei W (2009) Electrochemical Performance of LiV308-xClx Cathode Materials Synthesized by a Low Temperature Solid State Method Chinese Journal of Chemistry 27:1093-1098 doi:doi:10.1002/cjoc.200990182

Li N, Gong Hx, Qian Yt (2013b) Orthorhombic $\gamma \mathrm{LiV}_{2} \mathrm{O}_{5}$ as Cathode Materials in Lithium-Ion Batteries: Synthesis and Property Chinese Journal of Chemical Physics 26:597-600 doi:10.1063/1674-0068/26/05/597-600

Li W, Currie JC (1997) Morphology Effects on the Electrochemical Performance of $\mathrm{LiNi}_{1}$ - $\times \mathrm{Co}_{\mathrm{x}} \mathrm{O}_{2}$ Journal of The Electrochemical Society 144:2773-2779 doi:10.1149/1.1837894

Li W, Currie JC, Wolstenholme J (1997) Influence of morphology on the stability of $\mathrm{LiNiO}_{2}$ Journal of Power Sources 68:565-569 doi:https://doi.org/10.1016/S03787753(96)02566-9

Li W, Zhu L, Yu Z, Xie L, Cao X (2017b) LiV ${ }_{3} \mathrm{O}_{8}$ /Polytriphenylamine Composites with Enhanced Electrochemical Performances as Cathode Materials for Rechargeable Lithium Batteries Materials 10:344

Li X, Su Z, Wang Y (2018c) Electrochemical properties of monoclinic and orthorhombic $\mathrm{LiMnO}_{2}$ synthesized by a one-step hydrothermal method Journal of Alloys and Compounds 735:2182-2189 doi:10.1016/j.jallcom.2017.11.384

$\mathrm{Li} X$ et al. (2017c) Improved rate capability of a $\mathrm{LiNi}_{1 / 3} \mathrm{CO}_{\frac{1}{3}} \mathrm{Mn}_{1 / 3} \mathrm{O}_{2} / \mathrm{CNT} /$ graphene hybrid material for Li-ion batteries RSC Advances 7:24359-24367 doi:10.1039/C7RA03438E

Li Y, Liu J, Lei Y, Lai C, Xu Q (2017d) Enhanced electrochemical performances of $\mathrm{Na}$-doped cathode material $\mathrm{LiNi}_{1 / 3} \mathrm{CO}_{1 / 3} \mathrm{Mn}_{1 / 3} \mathrm{O}_{2}$ for lithium-ion batteries Journal of Materials Science 52:13596-13605 doi:10.1007/s10853-017-1449-z

Liang F, Yao Y, Dai Y, Yang B, Ma W, Watanabe T (2012) Preparation of porous structure LiFePO4/C composite by template method for lithium-ion batteries Solid State Ionics 214:31-36 doi:10.1016/j.ssi.2012.02.043

Liang $\mathrm{S}$ et al. (2014) $\mathrm{LiV}_{3} \mathrm{O}_{8} / \mathrm{Ag}$ composite nanobelts with enhanced performance as cathode material for rechargeable lithium batteries Journal of Alloys and Compounds 583:351-356 doi:https://doi.org/10.1016/j.jallcom.2013.08.124

Linden D, Reddy TB (2002) Handbook of batteries. McGraw-Hill, 
Ling GW et al. (2012) Structural and thermal stabilities of spinel $\mathrm{LiMn}_{2} \mathrm{O}_{4}$ materials under commercial power batteries cycling and abusive conditions International Journal of Electrochemical Science 7:2455-2467

Liu C, Neale ZG, Cao G (2016) Understanding electrochemical potentials of cathode materials in rechargeable batteries Materials Today 19:109-123 doi:https://doi.org/10.1016/j.mattod.2015.10.009

Liu D, Wang Z, Chen L (2006a) Comparison of structure and electrochemistry of Aland Fe-doped $\mathrm{LiNi}_{1 / 3} \mathrm{CO}_{\frac{1}{3}} \mathrm{Mn}_{1 / 3} \mathrm{O}_{2}$ Electrochimica Acta 51:4199-4203 doi:https://doi.org/10.1016/j.electacta.2005.11.045

Liu H, Cao Q, Fu LJ, Li C, Wu YP, Wu HQ (2006b) Doping effects of zinc on LiFePO cathode material for lithium ion batteries Electrochemistry Communications 8:1553-1557 doi:https://doi.org/10.1016/j.elecom.2006.07.014

Liu H, Wang Y, Wang K, Wang Y, Zhou H (2009a) Synthesis and electrochemical properties of single-crystalline $\mathrm{LiV}_{3} \mathrm{O}_{8}$ nanorods as cathode materials for rechargeable lithium batteries Journal of Power Sources 192:668-673 doi:https://doi.org/10.1016/j.jpowsour.2009.03.066

Liu H, Yang H, Huang T (2007) Synthesis, structure and electrochemical properties of one-dimensional nanometer materials $\mathrm{LiV}_{3} \mathrm{O}_{8}$ Materials Science and Engineering: B 143:60-63 doi:https://doi.org/10.1016/j.mseb.2007.07.010

Liu $\mathrm{H}$, Zhang $\mathrm{P}$, Li GC, Wu Q, Wu YP (2008) $\mathrm{LiFePO}_{4} / \mathrm{C}$ composites from carbothermal reduction method Journal of Solid State Electrochemistry 12:10111015 doi:10.1007/s10008-007-0478-y

Liu L et al. (2014) Studies of the electrochemical properties and thermal stability of $\mathrm{LiNi}_{1 / 3} \mathrm{CO}_{1 / 3} \mathrm{Mn}_{1 / 3} \mathrm{O}_{2} / \mathrm{LiFePO}_{4}$ composite cathodes for lithium-ion batteries lonics 20:1087-1093 doi:10.1007/s11581-013-1055-2

Liu P, Zhang J-G, Turner JA, Tracy CE, Benson DK, Bhattacharya RN (1998) Fabrication of $\mathrm{LiV}_{2} \mathrm{O}_{5}$ thin-film electrodes for rechargeable lithium batteries Solid State Ionics 111:145-151 doi:https://doi.org/10.1016/S0167-2738(98)00184-2

Liu Y, Chen B, Cao F, Zhao X, Yuan J (2011a) Synthesis of nano-architectured $\mathrm{LiNi} / \frac{1}{\mathrm{Mn}_{1 / 2} \mathrm{O}_{2}}$ spheres for high-performance rechargeable lithium-ion batteries via an in situ conversion route Journal of Materials Chemistry 21:10437-10441 doi:10.1039/C1JM10408J

Liu Y et al. (2018) Formation of size-dependent and conductive phase on lithium iron phosphate during carbon coating Nature Communications 9 doi:10.1038/s41467018-03324-7 
Liu Y, Zhou X, Guo Y (2009b) Structure and electrochemical performance of $\mathrm{LiV}_{3} \mathrm{O}_{8}$ synthesized by solid-state routine with quenching in freezing atmosphere Materials Chemistry and Physics 114:915-919 doi:https://doi.org/10.1016/j.matchemphys.2008.10.064

Liu Z, Zhen H, Kim Y, Liang C (2011b) Synthesis of $\mathrm{LiNiO}_{2}$ cathode materials with homogeneous Al doping at the atomic level Journal of Power Sources 196:1020110206 doi:https://doi.org/10.1016/j.jpowsour.2011.08.059

Long Y, Zhang Z, Wu Z, Su J, Lv X, Wen Y (2017) Microwave-assisted polyol synthesis of $\mathrm{LiMnPO}_{4} / \mathrm{C}$ and its use as a cathode material in lithium-ion batteries Particuology 33:42-49 doi:https://doi.org/10.1016/j.partic.2016.10.006

Lu Q, Hutchings GS, Zhou Y, Xin HL, Zheng H, Jiao F (2014) Nanostructured flexible Mg-modified $\mathrm{LiMnPO}_{4}$ matrix as high-rate cathode materials for Li-ion batteries Journal of Materials Chemistry A 2:6368-6373 doi:10.1039/C4TA00654B

Ludwig J, Marino C, Haering D, Stinner C, Gasteiger HA, Nilges T (2017) Morphologycontrolled microwave-assisted solvothermal synthesis of high-performance $\mathrm{LiCoPO}_{4}$ as a high-voltage cathode material for Li-ion batteries Journal of Power Sources 342:214-223 doi:10.1016/j.jpowsour.2016.12.059

Ludwig J, Nilges T (2018) Recent progress and developments in lithium cobalt phosphate chemistry- Syntheses, polymorphism and properties Journal of Power Sources 382:101-115 doi:https://doi.org/10.1016/j.jpowsour.2018.02.038

Manev V, Momchilov A, Nassalevska A, Pistoia G, Pasquali M (1995) A new approach to the improvement of $\mathrm{Li}_{1}+x \mathrm{~V}_{3} \mathrm{O}_{8}$ performance in rechargeable lithium batteries Journal of Power Sources 54:501-507 doi:https://doi.org/10.1016/03787753(94)02135-P

Martha SK et al. (2009) $\mathrm{LiMnPO}_{4}$ as an Advanced Cathode Material for Rechargeable Lithium Batteries Journal of The Electrochemical Society 156:A541-A552 doi:10.1149/1.3125765

Memm M, Hoffmann A, Wohlfahrt-Mehrens M (2018) Water-based LiNi $\mathrm{Co}_{1 / 3} \mathrm{Mn}_{1 / 3} \mathrm{O}_{2}$ cathodes with good electrochemical performance by use of additives Electrochimica Acta 260:664-673 doi:https://doi.org/10.1016/j.electacta.2017.12.014

Meng X, Cao H, Hao J, Ning P, Xu G, Sun Z (2018) Sustainable Preparation of $\mathrm{LiNi} 1 / 3 \mathrm{CO}_{1 / 3} \mathrm{Mnn}_{1 / 3} \mathrm{O}_{2}-\mathrm{V}_{2} \mathrm{O}_{5}$ Cathode Materials by Recycling Waste Materials of Spent Lithium-Ion Battery and Vanadium-Bearing Slag ACS Sustainable Chemistry \& Engineering 6:5797-5805 doi:10.1021/acssuschemeng.7b03880 
Meng X, Dou S, Wang W-I (2008) High power and high capacity cathode material $\mathrm{LiNi} \frac{1}{2} \mathrm{Mn}_{1 / 2} \mathrm{O}_{2}$ for advanced lithium-ion batteries Journal of Power Sources 184:489493 doi:https://doi.org/10.1016/j.jpowsour.2008.04.015

Meng YS, Ceder G, Grey CP, Yoon W-S, Shao-Horn Y (2004) Understanding the Crystal Structure of Layered LiNi $\mathrm{L}_{1 / 2} \mathrm{Mn}_{1 / 2} \mathrm{O}_{2}$ by Electron Diffraction and Powder Diffraction Simulation Electrochemical and Solid-State Letters 7:A155-A158 doi:10.1149/1.1718211

Migeon H-N, Zanne M, Gleitzer C, Aubry J (1978) The $\mathrm{Li}_{2} \mathrm{O}-\mathrm{NiO}-\mathrm{O}_{2}$ system at $670^{\circ} \mathrm{C}$ and the consequences of non-stoichiometry on the magnetic properties of the $\mathrm{Li}_{x} \mathrm{Ni}_{1-x} \mathrm{O}_{1 \pm y}$ phases Journal of Materials Science 13:461-466 doi:10.1007/bf00541793

Mizuno Y et al. (2012) Electrospinning synthesis of wire-structured $\mathrm{LiCoO}_{2}$ for electrode materials of high-power Li-ion batteries Journal of Physical Chemistry C 116:10774-10780 doi:10.1021/jp2123482

Mizuno Y et al. (2014) Fabrication of $\mathrm{LiCoO}_{2}$ Crystal Layers Using a Flux Method and Their Application for Additive-Free Lithium-Ion Rechargeable Battery Cathodes Crystal Growth \& Design 14:1882-1887 doi:10.1021/cg5000217

Mo R, Du Y, Rooney D, Ding G, Sun K (2016) Ultradispersed Nanoarchitecture of $\mathrm{LiV}_{3} \mathrm{O}_{8}$ Nanoparticle/Reduced Graphene Oxide with High-Capacity and Long-Life Lithium-Ion Battery Cathodes Scientific Reports 6:19843 doi:10.1038/srep19843

https://www.nature.com/articles/srep19843\#supplementary-information

Mogi M et al. (2013) Combined In-Situ X-ray Absorption Spectroscopy and FirstPrinciples Calculation Studies on Local Structural and Electronic Structural Alternations of $\mathrm{LiNi}_{1} /{ }_{3} \mathrm{Co}_{1} /{ }_{3} \mathrm{Mn}_{1} /{ }_{3} \mathrm{O}_{2}$ ECS Transactions 50:47-58 doi:10.1149/05026.0047ecst

Mohan P, Paruthimal Kalaignan G (2013) Electrochemical Behaviour of Surface Modified $\mathrm{SiO}_{2}$-Coated $\mathrm{LiNiO}_{2}$ Cathode Materials for Rechargeable Lithium-Ion Batteries vol 13. doi:10.1166/jnn.2013.7379

Mohan P, Paruthimal Kalaignan G, Muralidharan PVS (2012) Improved the electrochemical performance of $\left.\left.\mathrm{LiCe}_{1-x}\right) \mathrm{Ni}_{(}\right) \mathrm{O}_{2}$ cathode material for rechargeable lithium-ion battery vol 12. doi:10.1166/jnn.2012.6510

Mohtasham J (2015) Review Article-Renewable Energies Energy Procedia 74:12891297 doi:https://doi.org/10.1016/j.egypro.2015.07.774

Molenda J, Wilk P, Marzec J (2002) Structural, electrical and electrochemical properties of LiNiO2 Solid State lonics 146:73-79 doi:https://doi.org/10.1016/S0167-2738(01)00992-4 
Momchilov A, Manev V, Nassalevska A, Kozawa A (1993) Rechargeable lithium battery with spinel-related $\mathrm{MnO}_{2}$ II. Optimization of the LiMn2O4 synthesis conditions Journal of Power Sources 41:305-314 doi:10.1016/03787753(93)80048-T

Moradabadi A, Kaghazchi P (2015) Mechanism of Li intercalation/deintercalation into/from the surface of $\mathrm{LiCoO}_{2}$ Physical Chemistry Chemical Physics 17:2291722922 doi:10.1039/c5cp02246k

Moses AW, Flores HGG, Kim J-G, Langell MA (2007) Surface properties of $\mathrm{LiCoO}_{2}$, $\mathrm{LiNiO}_{2}$ and $\mathrm{LiNi}_{1-x} \mathrm{Co}_{x} \mathrm{O}_{2}$ Applied Surface Science 253:4782-4791 doi:https://doi.org/10.1016/j.apsusc.2006.10.044

Moshtev RV, Zlatilova P, Puresheva B, Manev V (1995) Material balance of petroleum coke/ $\mathrm{LiNiO}_{2}$ lithium-ion cells Journal of Power Sources 56:137-144 doi:https://doi.org/10.1016/0378-7753(95)80025-C

Mukai K et al. (2007) Microscopic magnetism in lithium insertion materials of $\mathrm{LiNi}_{1-x} \mathrm{Co}_{x} \mathrm{O}_{2}(x=0,1 / 4,1 / 21 / 2,3 / 4$, and 1$)$ Journal of Power Sources 174:843-846 doi:https://doi.org/10.1016/j.jpowsour.2007.06.105

Muto S, Tatsumi K, Kojima Y, Oka H, Kondo H, Horibuchi K, Ukyo Y (2012) Effect of $\mathrm{Mg}$-doping on the degradation of $\mathrm{LiNiO}_{2}$-based cathode materials by combined spectroscopic methods Journal of Power Sources 205:449-455 doi:https://doi.org/10.1016/j.jpowsour.2012.01.071

Na S-H, Kim H-S, Moon S-I (2005) The effect of Si doping on the electrochemical characteristics of $\mathrm{LiNi}_{x} \mathrm{Mn}_{\mathrm{y}} \mathrm{Co}\left({ }_{1-x-y}\right) \mathrm{O}_{2}$ Solid State Ionics 176:313-317 doi:https://doi.org/10.1016/j.ssi.2004.08.016

Nakamura K, Ohno H, Okamura K, Michihiro Y, Nakabayashi I, Kanashiro T (2000) On the diffusion of $\mathrm{Li}^{+}$defects in $\mathrm{LiCoO}_{2}$ and $\mathrm{LiNiO}_{2}$ Solid State lonics 135:143147 doi:https://doi.org/10.1016/S0167-2738(00)00293-9

Nam K-W, Yoon W-S, Shin H, Chung KY, Choi S, Yang X-Q (2009) In situ X-ray diffraction studies of mixed $\mathrm{LiMn}_{2} \mathrm{O}_{4}-\mathrm{LiNi}_{1 / 3} \mathrm{Co}_{1 / 3} \mathrm{Mn}_{1 / 3} \mathrm{O}_{2}$ composite cathode in Liion cells during charge-discharge cycling Journal of Power Sources 192:652-659 doi:https://doi.org/10.1016/j.jpowsour.2009.02.088

$\mathrm{Nie} \mathrm{H}$ et al. (2015) $\mathrm{LiCoO}_{2}$ : Recycling from spent batteries and regeneration with solid state synthesis Green Chemistry 17:1276-1280 doi:10.1039/c4gc01951b

Ohzuku T, Makimura Y (2006) Formation of solid solution and its effect on lithium insertion schemes for advanced lithium-ion batteries: X-ray absorption spectroscopy and $X$-ray diffraction of $\mathrm{LiCoO}_{2}, \mathrm{LiCO}_{1} /{ }_{2} \mathrm{Ni}_{1} /{ }_{2} \mathrm{O}_{2}$ and $\mathrm{LiNiO}_{2}$ Research on Chemical Intermediates 32:507-521 doi:10.1163/156856706777973745 
Onodera T, Kawaji J, Sato A, Okumura T (2017) Electrochemical performance of a newly-designed all-solid-state Li-ion battery with a $\mathrm{LiNi}_{1 / 3} \mathrm{Co}_{1 / 3} \mathrm{Mn}_{1 / 3} \mathrm{O}_{2}-\mathrm{LiVO}_{3}$ mono-particle layered cathode and a lamellar $\mathrm{LiVO}_{3}$ anode Journal of the Ceramic Society of Japan 125:494-499 doi:10.2109/jcersj2.16316

Ouyang CY, Shi SQ, Lei MS (2009) Jahn-Teller distortion and electronic structure of LiMn2O4 Journal of Alloys and Compounds 474:370-374 doi:10.1016/j.jallcom.2008.06.123

Ozawa H, Ogihara T, Mukoyama I, Myojin K, Aikiyo H, Okawa T, Harada A (2007) Synthesis of Lithium Manganate Powders by Spray Pyrolysis and its Application to Lithium Ion Batteries for Trams World Electric Vehicle Journal 1:19

Padhi AK, Nanjundaswamy KS, Goodenough JB (1997a) Phospho-olivines as positive-electrode materials for rechargeable lithium batteries Journal of the Electrochemical Society 144:1188-1194 doi:10.1149/1.1837571

Padhi AK, Nanjundaswamy KS, Goodenough JB (1997b) Phospho-olivines as Positive - Electrode Materials for Rechargeable Lithium Batteries Journal of The Electrochemical Society 144:1188-1194 doi:10.1149/1.1837571

Park M, Zhang X, Chung M, Less GB, Sastry AM (2010) A review of conduction phenomena in Li-ion batteries Journal of Power Sources 195:7904-7929 doi:https://doi.org/10.1016/j.jpowsour.2010.06.060

Park S-C, Kim Y-M, Han S-C, Ahn S, Ku C-H, Lee J-Y (2002) The elevated temperature performance of $\mathrm{LiMn}_{2} \mathrm{O}_{4}$ coated with $\mathrm{LiNi}_{1-x} \mathrm{Co}_{x} \mathrm{O}_{2}(\mathrm{X}=0.2$ and 1$)$ Journal of Power Sources 107:42-47 doi:https://doi.org/10.1016/S03787753(01)00978-8

Peng H, Zhu ZH, Huang PX, Li X (2015) Effects of Synthesis Temperature and Holding Time on the Electrochemical Properties of $\mathrm{LiNi}_{1 / 3} \mathrm{Co}_{\frac{1}{3}} \mathrm{Mn}_{1 / 3} \mathrm{O}_{2}$ Cathode Material Using Rheological Phase Method Materials Science Forum 814:351-357 doi:10.4028/www.scientific.net/MSF.814.351

Peng Z-d, Deng X-r, Du K, Hu G-r, Gao X-g, Liu Y-x (2008) Coating of $\mathrm{LiNi}=1 / 3 \mathrm{Mn}^{1 / 3} \mathrm{Co}^{1 / 3} \mathrm{O}_{2}$ cathode materials with alumina by solid-state reaction at room temperature Journal of Central South University of Technology 15:34-38 doi:10.1007/s11771-008-0008-9

Pistoia G (2013) Lithium-Ion Batteries: Advances and Applications. Elsevier Science, Qibing Z et al. (2017) Enhanced Electrochemical Capability of $\mathrm{LiNi}_{1 / 3} \mathrm{Co}_{1 / 3} \mathrm{Mn}_{1 / 3} \mathrm{O}_{2}$ Cathode Materials Coated with Fluoroborate Glass for Lithium - Ion Batteries ChemElectroChem 4:1199-1204 doi:doi:10.1002/celc.201600828 
Baddour-Hadjean, R., Marzouk, A., \& Pereira-Ramos, J. P. (2012) Structural modifications of $\mathrm{Li}_{x} \mathrm{~V}_{2} \mathrm{O}_{5}$ in a composite cathode $(0 \leq x<2)$ investigated by Raman micro spectrometry Journal of Raman Spectroscopy 43:153-160 doi:doi:10.1002/jrs.2984

Radin MD et al. (2017) Narrowing the Gap between Theoretical and Practical Capacities in Li-Ion Layered Oxide Cathode Materials Advanced Energy Materials 7 doi:10.1002/aenm.201602888

Rajammal K, Sivakumar D, Duraisamy N, Ramesh K, Ramesh S (2016) Effect of sintering temperature on structural properties of $\mathrm{LiMnPO}_{4}$ cathode materials obtained by sol-gel method Journal of Sol-Gel Science and Technology 80:514522 doi:10.1007/s10971-016-4111-3

Rao MM, Liebenow C, Jayalakshmi M, Wulff H, Guth U, Scholz F (2001) Hightemperature combustion synthesis and electrochemical characterization of $\mathrm{LiNiO}_{2}$, $\mathrm{LiCoO}_{2}$ and $\mathrm{LiMn}_{2} \mathrm{O}_{4}$ for lithium-ion secondary batteries Journal of Solid State Electrochemistry 5:348-354 doi:10.1007/s100080000157

Ren H, Huang Y, Wang Y, Li Z, Cai P, Peng Z, Zhou Y (2009) Effects of different carbonate precipitators on $\mathrm{LiNi}_{1 / 3} \mathrm{CO}_{\frac{1}{3}} \mathrm{Mn}_{\frac{1}{3}} \mathrm{O}_{2}$ morphology and electrochemical performance Materials Chemistry and Physics 117:41-45 doi:https://doi.org/10.1016/j.matchemphys.2009.01.002

Ren H, Wang Y, Li D, Ren L, Peng Z, Zhou Y (2008) Synthesis of $\mathrm{LiNi}_{1 / 3} \mathrm{CO}_{1 / 3} \mathrm{Mn}_{1 / 3} \mathrm{O}_{2}$ as a cathode material for lithium battery by the rheological phase method Journal of Power Sources 178:439-444 doi:https://doi.org/10.1016/j.jpowsour.2007.12.004

Rocquefelte X, Boucher F, Gressier P, Ouvrard G (2003) First-Principle Study of the Intercalation Process in the $\mathrm{Li}_{\mathrm{x}} \mathrm{V}_{2} \mathrm{O}_{5}$ System Chemistry of Materials 15:1812-1819 doi:10.1021/cm021254h

Rodrigues S, Munichandraiah N, Shukla AK (2001) Novel solution-combustion synthesis of $\mathrm{LiCoO} 2$ and its characterization as cathode material for lithium-ion cells Journal of Power Sources 102:322-325 doi:10.1016/S0378-7753(01)007704

Rosaiah P, Hussain OM, Zhu J, Qiu Y (2017) Spectroscopic and Electrochemical Properties of Lithium-Rich $\mathrm{LiFePO}_{4}$ Cathode Synthesized by Solid-State Reaction Journal of Electronic Materials 46:4865-4874 doi:10.1007/s11664-017-5474-0

Rougier A, Saadoune I, Gravereau P, Willmann P, Delmasa C (1996) Effect of cobalt substitution on cationic distribution in $\mathrm{LiNi}_{1}-y \mathrm{Co}_{\mathrm{y}} \mathrm{O}_{2}$ electrode materials Solid State Ionics 90:83-90 doi:https://doi.org/10.1016/S0167-2738(96)00370-0 
Sakunthala A, Reddy MV, Selvasekarapandian S, Chowdari BVR, Nithya H, Christopher Selvin P (2010) Synthesis and electrochemical studies on $\mathrm{LiV}_{3} \mathrm{O}_{8}$ Journal of Solid State Electrochemistry 14:1847-1854 doi:10.1007/s10008-0101044-6

Samarasingha P, Tran-Nguyen D-H, Behm M, Wijayasinghe A (2008) $\mathrm{LiNi}_{1 / 3} \mathrm{Mn}_{1 / 3} \mathrm{CO}_{1 / 3} \mathrm{O}_{2}$ synthesized by the Pechini method for the positive electrode in Li-ion batteries: Material characteristics and electrochemical behaviour Electrochimica Acta 53:7995-8000 doi:https://doi.org/10.1016/j.electacta.2008.06.003

Sasaki T et al. (2009) Capacity-Fading Mechanisms of $\mathrm{LiNiO}_{2}$-Based Lithium-Ion Batteries: I. Analysis by Electrochemical and Spectroscopic Examination Journal of The Electrochemical Society 156:A289-A293 doi:10.1149/1.3076136

Sathiya M, Prakash AS, Ramesha K, Shukla AK (2009) Rapid synthetic routes to prepare $\mathrm{LiNi}_{1 / 3} \mathrm{Mn}_{1 / 3} \mathrm{CO}_{1 / 3} \mathrm{O}_{2}$ as a high voltage, high-capacity Li-ion battery cathode material Materials Research Bulletin 44:1990-1994 doi:https://doi.org/10.1016/j.materresbull.2009.06.007

Satou Y, Komine S, Shimizu S (2017) Orbital-Specific observation of $\mathrm{O}_{2 p}$ and $\mathrm{Ni}_{3} \mathrm{~d}$ electrons in $\mathrm{LiNi}_{1 / 2} \mathrm{Mn}_{1 / 2} \mathrm{O}_{2}$, a cathode material for lithium-ion batteries AIP Advances 7:095117 doi:10.1063/1.4996705

Scrosati B, Garche J (2010) Lithium batteries: Status, prospects and future Journal of Power Sources 195:2419-2430 doi:https://doi.org/10.1016/j.jpowsour.2009.11.048

Shandilya M, Rai R, Singh J (2016) Review: hydrothermal technology for smart materials Advances in Applied Ceramics 115:354-376 doi:10.1080/17436753.2016.1157131

Shao-Horn Y, Hackney SA, Armstrong AR, Bruce PG, Gitzendanner R, Johnson CS, Thackeray MM (1999) Structural characterization of layered LiMnO2 electrodes by electron diffraction and lattice imaging Journal of the Electrochemical Society 146:2404-2412 doi:10.1149/1.1391949

Shen B-J, Ma J-S, Wu H-C, Lu C-H (2008) Microwave-mediated hydrothermal synthesis and electrochemical properties of $\mathrm{LiNi}^{1} / 3 \mathrm{Co}^{1} / 3 \mathrm{Mn}^{1} / 3 \mathrm{O}_{2}$ powders Materials Letters 62:4075-4077 doi:https://doi.org/10.1016/j.matlet.2008.05.034

Sheu SP, Shih IC, Yao CY, Chen JM, Huang WM (1997) Studies of $\mathrm{LiNiO}_{2}$ in lithiumion batteries Journal of Power Sources 68:558-560 doi:https://doi.org/10.1016/S0378-7753(97)02526-3 
Shlyakhtin OA, Yoon YS, Choi SH, Oh Y-J (2004) Freeze-drying synthesis of $\mathrm{LiNi} \mathrm{i}_{1 / 2} \mathrm{Mn}_{1 / 2} \mathrm{O}_{2}$ cathode materials Electrochimica Acta 50:505-509 doi:https://doi.org/10.1016/j.electacta.2004.05.051

Singh L, Kumar A, Lee H, Lee J, Ji M, Lee Y (2018) Ultrafast auto flame synthesis for the mass production of $\mathrm{LiCoO}_{2}$ as a cathode material for $\mathrm{Li}$-ion batteries Journal of Solid State Electrochemistry:1-8 doi:10.1007/s10008-018-3972-5

Song H, Liu Y, Zhang C, Liu C, Cao G (2015) Mo-doped LiV $_{3} \mathrm{O}_{8}$ nanorod-assembled nanosheets as a high performance cathode material for lithium ion batteries Journal of Materials Chemistry A 3:3547-3558 doi:10.1039/C4TA05616G

Song MY, Kim HU, Park HR (2014) Electrochemical properties of $\mathrm{LiNiO}_{2}$ cathode after $\mathrm{TiO}_{2}$ or $\mathrm{ZnO}$ addition Ceramics International 40:4219-4224 doi:https://doi.org/10.1016/j.ceramint.2013.08.084

Sun C-F, Amruthnath N, Yu J-S, Li W-J (2016a) Enhanced electrochemical

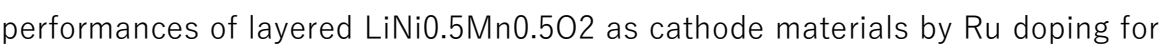
lithium-ion batteries lonics 22:1501-1508 doi:10.1007/s11581-016-1751-9

Sun $\mathrm{D}$ et al. (2015) Multi-layered $\mathrm{Al}_{2} \mathrm{O}_{3} / \mathrm{Li}_{x} \mathrm{~V}_{2} \mathrm{O}_{5} / \mathrm{LiV}_{3} \mathrm{O}_{8}$ nanoflakes with superior cycling stability as cathode material for Li-ion battery Electrochimica Acta 157:211-217 doi:https://doi.org/10.1016/j.electacta.2015.01.081

Sun $G$ et al. (2018) Synergistic effects of ion doping and surface-modifying for lithium transition-metal oxide: Synthesis and characterization of $\mathrm{La}_{2} \mathrm{O}_{3}$-modified $\mathrm{LiNi}_{1 / 3} \mathrm{CO}_{1 / 3} \mathrm{Mn}_{1 / 3} \mathrm{O}_{2} \quad$ Electrochimica Acta 272:11-21 doi:https://doi.org/10.1016/j.electacta.2018.03.175

Sun J, Jiao L, Wei X, Peng W, Liu L, Yuan H (2010) Effect of PEG molecular weight on the crystal structure and electrochemical performance of $\mathrm{LiV}_{3} \mathrm{O}_{8}$ Journal of Solid State Electrochemistry 14:615-619 doi:10.1007/s10008-009-0829-y

Sun $\mathrm{K}$ et al. (2016b) Hybrid $\mathrm{LiV}_{3} \mathrm{O}_{8} /$ carbon encapsulated $\mathrm{Li}_{1.2} \mathrm{Mn}_{0.54} \mathrm{Co}_{0.13} \mathrm{Ni}_{0.13} \mathrm{O}_{2}$ with improved electrochemical properties for lithium-ion batteries RSC Advances 6:28729-28736 doi:10.1039/C6RA02688E

Sun Y, Wan P, Pan J, Xu C, Liu X (2006a) Low temperature synthesis of layered $\mathrm{LiNiO}_{2}$ cathode material in air atmosphere by ion exchange reaction Solid State Ionics 177:1173-1177 doi:https://doi.org/10.1016/j.ssi.2006.04.050

Sun Y, Xia Y, Shiosaki Y, Noguchi H (2006b) Preparation and electrochemical properties of $\mathrm{LiCoO}_{2}-\mathrm{LiNi} \frac{1}{2} \mathrm{Mn}_{1 / 2} \mathrm{O}_{2}-\mathrm{Li}_{2} \mathrm{MnO}_{3}$ solid solutions with high $\mathrm{Mn}$ contents Electrochimica Acta 51:5581-5586 doi:https://doi.org/10.1016/j.electacta.2006.02.041 
T. BP, Daniel PY, A. CP, Ram S, J. RM (2013) Chemical Inhomogeneity, Short - Range Order, and Magnetism in the $\mathrm{LiNiO}_{2}$ - NiO Solid Solution Chemistry - A European Journal 19:14521-14531 doi:doi:10.1002/chem.201301451

Tang C-Y, Feng L, Haasch RT, Dillon SJ (2018) Surface redox on Li [ $\left.\mathrm{LiNi}_{1 / 3} \mathrm{CO}_{\frac{1}{3} 3} \mathrm{Mn}_{1 / 3}\right]_{2}$ characterized by insitu X-ray photoelectron spectroscopy and insitu Auger electron spectroscopy Electrochimica Acta 277:197-204 doi:https://doi.org/10.1016/j.electacta.2018.04.199

Thackeray MM, Johnson PJ, de Picciotto LA, Bruce PG, Goodenough JB (1984) Electrochemical extraction of lithium from $\mathrm{LiMn}_{2} \mathrm{O}_{4}$ Materials Research Bulletin 19:179-187 doi:10.1016/0025-5408(84)90088-6

Thirunakaran R, Ravikumar R, Gopukumar S, Sivashanmugam A (2013) Electrochemical evaluation of dual-doped $\mathrm{LiMn}_{2} \mathrm{O}_{4}$ spinels synthesized via coprecipitation method as cathode material for lithium rechargeable batteries Journal of Alloys and Compounds 556:266-273 doi:10.1016/j.jallcom.2012.12.053

Tian M (2017) Effects of Sintering Time on the Performance of $\mathrm{LiNi}_{1 / 3} \mathrm{Co}_{1 / 3} \mathrm{Mn}_{1 / 3} \mathrm{O}_{2}$ Synthesized by High Temperature Ball Milling Method vol 12. doi:10.20964/2017.08.42

Tian M et al. (2016) Phase structure and electrochemical performance of layeredspinel integrated $\mathrm{LiNi}_{1 / 2} \mathrm{Mn}_{1 / 2} \mathrm{O}_{2}-\mathrm{LiMn}_{1.9} \mathrm{Al}_{0.1} \mathrm{O}_{4}$ composite cathodes for lithium-ion batteries Ceramics International 42:16916-16926 doi:https://doi.org/10.1016/j.ceramint.2016.07.191

Vediappan $\mathrm{K}$ et al. (2014) Stirring effect in hydrothermal synthesis of nano C$\mathrm{LiFePO}_{4}$ Journal of Power Sources 266:99-106 doi:10.1016/j.jpowsour.2014.05.005

Venkateswara Rao C, Leela Mohana Reddy A, Ishikawa Y, Ajayan PM (2011) $\mathrm{LiNi} 1 / 3 \mathrm{Co}_{1 / 3} \mathrm{Mn}_{1 / 3} \mathrm{O}_{2} \mathrm{LiNi}_{1 / 3} \mathrm{Co}_{1 / 3} \mathrm{Mn}_{1 / 3} \mathrm{O}_{2}$-Graphene Composite as a Promising Cathode for Lithium-Ion Batteries ACS Applied Materials \& Interfaces 3:2966-2972 doi:10.1021/am200421h

Wang C, Ma X, Zhou L, Cheng J, Sun J, Zhou Y (2007a) Study on the rapid synthesis of $\mathrm{LiNi}_{1-x} \mathrm{Co}_{x} \mathrm{O}_{2}$ cathode material for lithium secondary battery Electrochimica Acta 52:3022-3027 doi:https://doi.org/10.1016/j.electacta.2006.09.047

Wang D, Cao L, Huang J, Wu J (2012) Synthesis and electrochemical properties of $\mathrm{LiV}_{3} \mathrm{O}_{8}$ via an improved sol-gel process Ceramics International 38:2647-2652 doi:https://doi.org/10.1016/j.ceramint.2011.11.030 
Wang F, Yang J, NuLi Y, Wang J (2010) Highly promoted electrochemical performance of $5 \mathrm{~V}$ LiCoPO4 cathode material by addition of vanadium Journal of Power Sources 195:6884-6887 doi:10.1016/j.jpowsour.2010.04.071

Wang J, Sun X (2015) Olivine $\mathrm{LiFePO}_{4}$ : The remaining challenges for future energy storage Energy and Environmental Science 8:1110-1138 doi:10.1039/c4ee04016c

Wang K, Cai R, Yuan T, Yu X, Ran R, Shao Z (2009) Process investigation, electrochemical characterization and optimization of $\mathrm{LiFePO}_{4} / \mathrm{C}$ composite from mechanical activation using sucrose as carbon source Electrochimica Acta 54:2861-2868 doi:10.1016/j.electacta.2008.11.012

Wang L, Zhou F, Meng YS, Ceder G (2007b) First-principles study of surface properties of LiFeP O4: Surface energy, structure, Wulff shape, and surface redox potential Physical Review B - Condensed Matter and Materials Physics 76 doi:10.1103/PhysRevB.76.165435

Wang M, Navrotsky A (2004) Enthalpy of formation of $\mathrm{LiNiO}_{2}, \mathrm{LiCoO}_{2}$ and their solid solution, LiNi1-xCoxO2 Solid State lonics 166:167-173 doi:https://doi.org/10.1016/j.ssi.2003.11.004

Wang R et al. (2017) Effect of Different Binders on the Electrochemical Performance of Metal Oxide Anode for Lithium-Ion Batteries Nanoscale Research Letters 12:575 doi:10.1186/s11671-017-2348-6

Wang $Y$ et al. (2018) Layered oxides- $\mathrm{LiNi}_{1 / 3} \mathrm{CO}_{\frac{1}{3}} \mathrm{Mn}_{1 / 3} \mathrm{O}_{2}$ as anode electrode for symmetric rechargeable lithium-ion batteries Journal of Power Sources 378:516521 doi:https://doi.org/10.1016/j.jpowsour.2017.12.043

Wenming $\mathrm{T}$ et al. (2018) Synthesis of mesoporous orthorhombic $\mathrm{LiMnO}_{2}$ cathode materials via a one-step flux method for high performance lithium-ion batteries Materials Research Express 5:065511

Wolfenstine J (2006) Electrical conductivity of doped $\mathrm{LiCoPO}_{4}$ Journal of Power Sources 158:1431-1435 doi:10.1016/j.jpowsour.2005.10.072

Wolfenstine J, Read J, Allen JL (2007) Effect of carbon on the electronic conductivity and discharge capacity $\mathrm{LiCoPO}_{4}$ Journal of Power Sources 163:1070-1073 doi:10.1016/j.jpowsour.2006.10.010

Wu B et al. (2016) Controlled solvothermal synthesis and electrochemical performance of LiCoPO4 submicron single crystals as a cathode material for lithium ion batteries Journal of Power Sources 304:181-188 doi:10.1016/j.jpowsour.2015.11.023 
Wu F, Wang L, Wu C, Bai Y, Wang $F$ (2009) Study on $\mathrm{Li}_{1}+x \mathrm{~V}_{3} \mathrm{O}_{8}$ synthesized by microwave sol-gel route Materials Chemistry and Physics 115:707-711 doi:https://doi.org/10.1016/j.matchemphys.2009.02.007

Wu F, Wang M, Su Y, Bao L, Chen S (2010) A novel method for synthesis of layered $\mathrm{LiNi}_{1 / 3} \mathrm{Mn}_{1 / 3} \mathrm{Co}_{1 / 3} \mathrm{O}_{2}$ as cathode material for lithium-ion battery Journal of Power Sources 195:2362-2367 doi:https://doi.org/10.1016/j.jpowsour.2009.10.043

Wu HM, Tu JP, Yuan YF, Li Y, Zhao XB, Cao GS (2005) Structural, morphological and electrochemical characteristics of spinel LiMn2O4 prepared by spray-drying method Scripta Materialia 52:513-517 doi:10.1016/j.scriptamat.2004.10.037

Wu M, Chen A, Xu R, Li Y (2003a) Nanocrystalline $\mathrm{LiNi}_{1-x} \mathrm{Co}_{x} \mathrm{O}_{2}$ cathode materials prepared by a gel-combustion process Materials Science and Engineering: $B$ 99:336-339 doi:https://doi.org/10.1016/S0921-5107(02)00484-1

Wu Q, Li X, Yan M, Jiang Z (2003b) Electrochemical properties of submicron-sized layered $\mathrm{LiNi}_{1 / 2} \mathrm{Mn}_{1 / 2} \mathrm{O}_{2}$ Electrochemistry Communications 5:878-882 doi:https://doi.org/10.1016/j.elecom.2003.08.011

Wu X et al. (2018a) Analysis of the effects of different carbon coating strategies on structure and electrochemical behavior of $\mathrm{LiCoPO}_{4}$ material as a high-voltage cathode electrode for lithium-ion batteries Electrochimica Acta 279:108-117 doi:10.1016/j.electacta.2018.05.067

Wu X, Zhao S-X, Wei L, Deng H, Nan C-W (2018b) Improving the structure stability and electrochemical performance of $\mathrm{Li}_{2} \mathrm{MnSiO}_{4} / \mathrm{C}$ cathode materials by Ti-doping and porous microstructure Journal of Alloys and Compounds 735:1158-1166 doi:https://doi.org/10.1016/j.jallcom.2017.11.230

Wu Y (2015) Lithium-Ion Batteries: Fundamentals and Applications. CRC Press,

Xia H, Luo Z, Xie J (2012) Nanostructured LiMn ${ }_{2} \mathrm{O}_{4}$ and their composites as highperformance cathodes for lithium-ion batteries Progress in Natural Science: Materials International 22:572-584 doi:10.1016/j.pnsc.2012.11.014

Xia H, Tang SB, Lu L (2008) Novel synthesis and electrochemical behavior of layered $\mathrm{LiNi}_{1 / 2} \mathrm{Mn}_{1 / 2} \mathrm{O}_{2}$ Journal of Alloys and Compounds 449:296-299 doi:https://doi.org/10.1016/j.jallcom.2006.02.097

Xiao H, Wang Y, Xie K, Cheng S, Cheng X (2018) High capacitance $\mathrm{LiMn}_{2} \mathrm{O}_{4}$ microspheres with different microstructures as cathode material for aqueous asymmetric supercapacitors Journal of Alloys and Compounds 738:25-31 doi:10.1016/j.jallcom.2017.12.143 
Xiao L, Liu X, Zhao X, Liang H, Liu H (2011) Preparation of $\mathrm{LiNi}_{1 / 2} \mathrm{Mn}_{1 / 2} \mathrm{O}_{2}$ cathode materials by urea hydrolysis coprecipitation Solid State Ionics 192:335-338 doi:https://doi.org/10.1016/j.ssi.2010.06.039

Xiao X, Wang L, Wang D, He X, Peng Q, Li Y (2009) Hydrothermal synthesis of orthorhombic $\mathrm{LiMnO}_{2}$ nano-particles and $\mathrm{LiMnO}_{2}$ nanorods and comparison of their electrochemical performances Nano Research 2:923-930 doi:10.1007/s12274-009-9094-8

Xiong X, Wang Z, Yan G, Guo H, Li X (2014) Role of $\mathrm{V}_{2} \mathrm{O}_{5}$ coating on $\mathrm{LiNiO}_{2}$-based materials for lithium-ion battery Journal of Power Sources 245:183-193 doi:https://doi.org/10.1016/j.jpowsour.2013.06.133

Xu F, Yan H, Chen J, Zhang Z, Fan C (2018) Improving electrochemical properties of $\mathrm{LiNi} 1 / 3 \mathrm{CO}_{1 / 3} \mathrm{Mn}_{1 / 3} \mathrm{O}_{2}$ by enhancing thermal decomposition of carbonates to synthesize ultrafine powders Journal of Electroanalytical Chemistry 820:118-122 doi:https://doi.org/10.1016/j.jelechem.2018.04.069

Xu Z, Gao L, Liu Y, Li L (2016) Review—Recent Developments in the Doped LiFePO4 Cathode Materials for Power Lithium Ion Batteries Journal of The Electrochemical Society 163:A2600-A2610 doi:10.1149/2.0411613jes

Yamada S, Fujiwara M, Kanda M (1995) Synthesis and properties of $\mathrm{LiNiO}_{2}$ as cathode material for secondary batteries Journal of Power Sources 54:209-213 doi:https://doi.org/10.1016/0378-7753(94)02068-E

Yan J, Liu H, Wang Y, Zhao X, Mi Y, Xia B (2015) Enhanced high-temperature cycling stability of $\mathrm{LiNi}_{1 / 3} \mathrm{CO}_{1 / 3} \mathrm{Mn}_{1 / 3} \mathrm{O}_{2}$-coated $\mathrm{LiMn}_{2} \mathrm{O}_{4}$ as cathode material for lithium ion batteries Ionics 21:1835-1842 doi:10.1007/s11581-015-1371-9

Yano A, Ueda A, Shikano M, Sakaebe H, Ogumi Z (2016) Surface Structure and HighVoltage Charging/Discharging Performance of Low-Content Zr-Oxide-Coated $\mathrm{LiNi} \frac{1}{3} \mathrm{Co}_{1 / 3} \mathrm{Mnn}_{1 / 3} \mathrm{O}_{2}$ Journal of The Electrochemical Society 163:A75-A82 doi:10.1149/2.0211602jes

Yao J, Shen C, Zhang P, Gregory DH, Wang L (2012) Enhanced cyclability of spinel $\mathrm{LiMn}_{2} \mathrm{O}_{4}$ by controlling the phase purity and structural strain Journal of Physics and Chemistry of Solids 73:1390-1395 doi:10.1016/j.jpcs.2012.07.006

Yi TF, Hao CL, Yue CB, Zhu RS, Shu J (2009) A literature review and test: Structure and physicochemical properties of spinel $\mathrm{LiMn}_{2} \mathrm{O}_{4}$ synthesized by different temperatures for lithium-ion battery Synthetic Metals 159:1255-1260 doi:10.1016/j.synthmet.2009.02.026

Yu F, Lim SH, Zhen Y, An Y, Lin J (2014) Optimized electrochemical performance of three-dimensional porous $\mathrm{LiFePO}_{4} / \mathrm{C}$ microspheres via microwave irradiation 
assisted synthesis Journal of Power Sources 271:231-238 doi:10.1016/j.jpowsour.2014.08.009

Yuan T, Liu H, Gu Y, Cui H, Wang Y (2016) The phase structure and electrochemical performance of $x \mathrm{Li}_{2} \mathrm{MnO}_{3} \cdot\left({ }_{1-x}\right) \mathrm{LiNi}_{1 / 3} \mathrm{CO}_{1 / 3} \mathrm{Mn}_{1 / 3} \mathrm{O}_{2}$ during the synthesis and chargedischarge process Applied Physics A 122:812 doi:10.1007/s00339-016-0306-2

Zeng J et al. (2018) Facile triethanolamine-assisted combustion synthesized layered LiNi1/3Co1/3Mn1/302 cathode materials with enhanced electrochemical performance for lithium-ion batteries Journal of Alloys and Compounds 735:19771985 doi:https://doi.org/10.1016/j.jallcom.2017.11.321

Zhang B, Chen G, Xu P, Lv Z (2007) Effect of ultrasonic irradiation on the structure and electrochemical properties of cathode material $\mathrm{LiNi}_{1 / 2} \mathrm{Mnn}_{1 / 2} \mathrm{O}_{2}$ for lithium batteries Solid State lonics 178:1230-1234 doi:https://doi.org/10.1016/j.ssi.2007.06.010

Zhang C et al. (2018a) Significant Improvement on Electrochemical Performance of $\mathrm{LiMn}_{2} \mathrm{O}_{4}$ at Elevated Temperature by Atomic Layer Deposition of $\mathrm{TiO}_{2}$ Nanocoating ACS Sustainable Chemistry and Engineering 6:7890-7901 doi:10.1021/acssuschemeng.8b01081

Zhang J, Wu Z, Hua W, Liu H, Zhong B (2015) High-performance porous spherical cathode materials based on $\mathrm{CaCO}_{3}$-template synthesis of $\mathrm{LiNi}_{1 / 3} \mathrm{Co}_{1 / 3} \mathrm{Mn}_{1 / 3} \mathrm{O}_{2}$ for lithium-ion batteries Ionics 21:3151-3158 doi:10.1007/s11581-015-1501-4

Zhang L-L, Wang J-Q, Yang X-L, Liang G, Li T, Yu P-L, Ma D (2018b) Enhanced Electrochemical Performance of Fast Ionic Conductor $\mathrm{LiTi}_{2}\left(\mathrm{PO}_{4}\right)_{3}$-Coated $\mathrm{LiNi}_{1 / 3} \mathrm{CO}_{1 / 3} \mathrm{Mn}_{1 / 3} \mathrm{O}_{2}$ Cathode Material ACS Applied Materials \& Interfaces 10:1166311670 doi:10.1021/acsami.7b19692

Zhang P, Zhang L, Ren X, Yuan Q, Liu J, Zhang Q (2011a) Preparation and electrochemical properties of $\mathrm{LiNi}_{1 / 3} \mathrm{CO}_{1 / 3} \mathrm{Mnn}_{1 / 3} \mathrm{O}_{2}-\mathrm{PPy}$ composites cathode materials for lithium-ion battery Synthetic Metals 161:1092-1097 doi:https://doi.org/10.1016/j.synthmet.2011.03.021

Zhang W-J (2011) Structure and performance of $\mathrm{LiFePO}_{4}$ cathode materials: A review Journal of Power Sources 196:2962-2970 doi:https://doi.org/10.1016/j.jpowsour.2010.11.113

Zhang X, Mauger A, Jiang W, Groult H, Julien CM (2011b) Diffusion of Li+ lons in $\mathrm{LiNi} 1 \frac{1}{3} \mathrm{Co}_{1 / 3} \mathrm{Mn}_{1 / 3} \mathrm{O}_{2}$ ECS Transactions 35:89-94 doi:10.1149/1.3654205

Zhang Y, Wang C-Y (2009) Cycle-Life Characterization of Automotive Lithium-Ion Batteries with $\mathrm{LiNiO}_{2}$ Cathode Journal of The Electrochemical Society 156:A527A535 doi:10.1149/1.3126385 
Zhang Y et al. (2017) Sacrificial Template Strategy toward a Hollow LiNi $\mathrm{Li}_{3 / 3} \mathrm{Co}_{\frac{1}{3}} \mathrm{Mn}_{1 / 3} \mathrm{O}_{2}$ Nanosphere Cathode for Advanced Lithium-Ion Batteries ACS Omega 2:75937599 doi:10.1021/acsomega.7b00764

Zhang Z, He W, Li G, Xia J, Hu H, Huang J (2014) Ultrasound-assisted Hydrothermal Renovation of $\mathrm{LiCoO}_{2}$ from the cathode of spent lithium-ion batteries International Journal of Electrochemical Science 9:3691-3700

Zhang Z, Zhang SS (2015) Rechargeable batteries : materials, technologies and new trends.

Zhao H, Hu ZB, Xiao XL, Liu XF (2014) Hydrothermal Synthesis and Electrochemical Performance of $\mathrm{LiNi}_{1 / 2} \mathrm{Mn}_{1 / 2} \mathrm{O}_{2}$ as Lithium-Ion Battery Cathode Applied Mechanics and Materials 672-674:638-645 doi:10.4028/www.scientific.net/AMM.672674.638

Zhao J, Wang Z, Guo H, Li X (2017) Enhanced electrochemical properties of $\mathrm{LiNiO}_{2}$ based cathode materials by nanoscale manganese carbonate treatment Applied Surface Science 403:426-434 doi:https://doi.org/10.1016/j.apsusc.2017.01.089

Zhao M, Zheng Q, Wang F, Dai W, Song X (2011) Electrochemical performance of high specific capacity of lithium-ion cell $\mathrm{LiV}_{3} \mathrm{O}_{8} / / \mathrm{LiMn}_{2} \mathrm{O}_{4}$ with $\mathrm{LiNO}_{3}$ aqueous solution electrolyte Electrochimica Acta 56:3781-3784 doi:https://doi.org/10.1016/j.electacta.2011.02.057

Zheng H, Chen X, Yang Y, Li L, Li G, Guo Z, Feng C (2017) Self-Assembled $\mathrm{LiNi}_{1 / 3} \mathrm{CO}_{1 / 3} \mathrm{Mn}_{1 / 3} \mathrm{O}_{2}$ Nanosheet Cathode with High Electrochemical Performance ACS Applied Materials \& Interfaces 9:39560-39568 doi:10.1021/acsami.7b10264

Zheng X, Li X, Wang Z, Guo H, Huang Z, Yan G, Wang D (2016) Investigation and improvement on the electrochemical performance and storage characteristics of $\mathrm{LiNiO}_{2}$-based materials for lithium-ion battery Electrochimica Acta 191:832-840 doi:https://doi.org/10.1016/j.electacta.2016.01.142

Li, Z. Y., \& Wu, Q. H. (2008) Electronic Structures of $\mathrm{Li}_{x} \mathrm{~V}_{2} \mathrm{O}_{5}(x=0.5$ and 1$)$ : $A$ Theoretical Study ChemPhysChem 9:300-304 doi:doi:10.1002/cphc.200700560

Zhong H, Sun M, Li Y, He J, Yang J, Zhang L (2016) The polyacrylic latex: an efficient water-soluble binder for the $\mathrm{LiNi}_{1 / 3} \mathrm{CO}_{1 / 3} \mathrm{Mn}_{1 / 3} \mathrm{O}_{2}$ cathode in $\mathrm{Li}$-ion batteries Journal of Solid State Electrochemistry 20:1-8 doi:10.1007/s10008-015-2967-8

Zhong Ren X, Shi C, Xin Zhang P, Hong Liu J (2012) Synthesis and Electrochemical Performance of $\mathrm{LiV}_{3} \mathrm{O}_{8} /$ MWCNTs Cathode Material for Lithium-Ion Batteries vol 454. doi:10.4028/scientific5/AMR.454.105 
Zhongxue C, Fei X, Shunan C, Zhengfeng L, Hanxi Y, Xinping A, Yuliang C (2017) High Rate, Long Lifespan $\mathrm{LiV}_{3} \mathrm{O}_{8}$ Nanorods as a Cathode Material for Lithium Ion Batteries Small 13:1603148 doi:doi:10.1002/smll.201603148

Zhou H, Li Y, Zhang J, Kang W, Yu DYW (2016) Low-temperature direct synthesis of layered $m$ - $\mathrm{LiMnO}_{2}$ for lithium-ion battery applications Journal of Alloys and Compounds 659:248-254 doi:10.1016/j.jallcom.2015.11.038

Zhu C, Wu Z, Xie J, Chen Z, Tu J, Cao G, Zhao X (2018a) Solvothermal-assisted morphology evolution of nanostructured $\mathrm{LiMnPO}_{4}$ as high-performance lithiumion batteries cathode Journal of Materials Science \& Technology doi:https://doi.org/10.1016/j.jmst.2018.04.017

Zhu L, Li W, Yu Z, Xie L, Cao X (2017) Synthesis and electrochemical performances of $\mathrm{LiV}_{3} \mathrm{O}_{8} /$ poly (3, 4-ethylene dioxythiophene) composites as cathode materials for rechargeable lithium batteries Solid State Ionics 310:30-37 doi:https://doi.org/10.1016/j.ssi.2017.08.002

Zhu L, Xie L, Cao X (2018b) LiV $\mathrm{O}_{8}$ /Polydiphenylamine Composites with Significantly Improved Electrochemical Behavior as Cathode Materials for Rechargeable Lithium Batteries ACS Applied Materials \& Interfaces 10:10909-10917 doi:10.1021/acsami.8b00364

Zhu W, Zhuang Z, Lin Z, Yang Y, Lin Y, Huang Z (2016) Enhanced electrochemical properties and thermal stability of $\mathrm{LiNi}_{1 / 3} \mathrm{Co}_{\frac{1}{3}} \mathrm{Mn}_{1 / 3} \mathrm{O}_{2}$ by surface modification with Eu2O3 Ionics 22:1533-1540 doi:10.1007/s11581-016-1681-6

Zhu X, Zhan H, Liu H, Zhou Y (2006) Synthesis and characterization of $\mathrm{LiNi}_{0.95}$ $x \mathrm{CO}_{x} \mathrm{Al}_{0.05} \mathrm{O}_{2}$ for lithium-ion batteries Rare Metals 25:303-308 doi:https://doi.org/10.1016/S1001-0521(06)60058-2

Ziolkowska DA, Jasinski JB, Hamankiewicz B, Korona KP, Wu SH, Czerwinski A (2016) In Situ XRD and TEM Studies of Sol-Gel-Based Synthesis of $\mathrm{LiFePO}_{4}$ Crystal Growth and Design 16:5006-5013 doi:10.1021/acs.cgd.6b00575 